DOE-EA-1104

Environmental Assessment

for

\title{
Consolidation of Certain Materials and Machines for Nuclear Criticality Experiments and Training
}

\author{
LOS ALAMOS NATIONAL LABORATORY \\ Los Alamos, New Mexico
}

FINAL DOCUMENT

\begin{abstract}
DISCLAIMER
This report was prepared as an account of work sponsored by an agency of the United States Government. Neither the United States Government nor any agency thereof, nor any of their employees, makes any warranty, express or implied, or assumes any legal liability or responsibility for the accuracy, completeness, or usefulness of any information, apparatus, product, or process disclosed, or represents that its use would not infringe privately owned rights. Reference herein to any specific commercial product, process, or service by trade name, trademark, manufacturer, or otherwise does not necessarily constitute or imply its endorsement, recommendation, or favoring by the United States Government or any agency thereof. The views and opinions of authors expressed herein do not necessarily state or reflect those of the United States Government or any agency thereof.
\end{abstract}

Date Prepared: May 21,1996

Prepared by: U.S. Department of Energy, Los Alamos Area Office OISTRIBUTION OF THIS DOCUMENT IS UALIMITED 


\title{
DOE/EA-- $1 / 04$
}

\section{RECEIVED}

\author{
JÜN 211996
}

OSTI

Department of Energy

Finding of No Significant Impact

Consolidation of Certain Materials and Machines for Nuclear Criticality

Experiments and Training

Los Alamos National Laboratory

U. S. Department of Energy

Los Alamos Area Office

528 35th Street

Los Alamos, NM 87544 
DEPARTIMENT OF ENERGY

FINDING OF NO SIGNIFICANT IMPACT

CONSOLIDATION OF CERTAIN MATERIALS AND MACHINES FOR NUCLEAR CRITICALITY EXPERIMENTS AND TRAINING

\section{LOS ALAMOS NATIONAL LABORATORY}

PROPOSED ACTION: In support of its assigned missions and because of the importance of avoiding nuclear criticality accidents, the Department of Energy (DOE) has, adopted a policy !: to reduce identifiable nuclear criticality safety risks and to protect the public, workers, government property and essential operations from the effects of a criticality accident. In support of this policy, the Los Alamos Critical Experiments Facility (LACEF) at the Los Alamos National Laboratory (LANL) Technical Area (TA) 18 provides a program of general purpose criticality experiments. This program, the only remaining one of its kind in the United States, seeks to maintain a sound basis of information for criticality control by covering the physical situations that the DOE will encounter in handling and storing fissionable material in the future, and ensuring the presence of a community of individuals competent in practicing this control.

In 1993, the Defense Nuclear Facilities Safety (Board), an oversight organization established under the Atomic Energy Act of 1954, approved and transmitted a recommendation to DOE that DOE continue its criticality experimental capability. In addition to citing the importance of avoiding criticality accidents, the Board stated its concern that the last remaining facility capable of general purpose criticality experimentation and criticality training may be terminated because of lack of funding. The United States Nuclear Regulatory Commission also endorsed the Board's recommendation 
in a letter to the Secretary of Energy. In its formal response, the DOE accepted the Board's recommendation and agreed to continue an experimentation program for general purpose criticality experiments and an education program for criticality safety professionals.

In the course of closing or changing the missions of various DOE facilities, certain nuclear materials and machines (mechanical systems designed to move special nuclear materials) used for criticality experiments are being designated as surplus to the requirements at these facilities. Four facilities, the Hanford Plant (Hanford) located in Richland, Washington; Sandia National Laboratory in Albuquerque, New Mexico (SNL/NM); Oak Ridge National Laboratory (ORNL) in Oak Ridge, Tennessee; and the Idaho National Engineering Laboratory (INEL) located in Idaho Falls, Idaho, have recently identified certain nuclear materials and machines used for criticality experiments that they consider surplus to their needs. In addition, LANL currently has highly enriched uranium hemishells (i.e., nesting shells) at LACEF that could also be used to conduct criticality experiments. The DOE now has the opportunity to consolidate these nuclear materials and machines within LACEF at $\cdots$.

LANL for continued use in its existing program of nuclear materials criticality training and experimentation, and manage these materials and machines in a manner that will maximize their utility. The Environmental Assessment (EA) for the Consolidation of Certain Materials and Machines for Nuclear Criticality Experiments and Training at TA-18, LANL, Los Alamos, New Mexico (DOE-EA-1104), May 1996, analyzes the DOE proposal to consolidate these nuclear materials and machines at LACEF for the purposes of criticality experimentation and training. 
The EA compares the effects of the proposed action with the effects of the no action alternative, which is not to consolidate these materials and machines at LANL and not to receive, store, and use these materials at LACEF. If the materials are not transported to -.. LANL, it is anticipated that they would remain at their current locations until another site was found that could use the materials for other purposes or until the materials were declared a waste. The nested shells that are currently at LACEF would continue to be used for training for their historical purpose. Because of anticipated and on-going changes to DOE missions and facilities, it is unlikely that these other DOE sites would again perform criticality-related work with these materials. No other site, except LANL, is expected to continue to perform the criticality experiments and training mission. Under the no action alternative, criticality experiments and training would continue to occur at LACEF using historically employed materials and machines. However, some criticality experimentation and training that would be unique to these identified materials and machines would not be done. This would affect the DOE's ability to study a wider variety of criticality scenarios and to provide the attendant training to current and new DOE employees, other federal employees, and members of national and international nuclear regulatory agencies. It would also affect the DOE's ability to perform certain types of calibration testing for criticality monitors and alarm systems. Although the no action alternative does not meet the DOE's purpose and need for action, it was analyzed in the EA to provide a baseline comparison with the proposed action.

DOE considered, but dismissed from further analysis, alternatives including (1) conducting general purpose criticality experiments and criticality training at an alternative DOE or LANL site, and (2) receiving and storing these materials at LANL, or an alternative DOE Site, but 
not using them to conduct general purpose criticality experiments or training. Since there are no existing alternative DOE or LANL sites that could perform general purpose criticality experiments and support a criticality training program, the first alternative does not meet the purpose and need for agency action, and was eliminated from further analysis in the EA. The second alternative, however, is feasible, and materials could be stored at various alternative locations. However, this alternative does not support the DOE's commitment to continue its on-going experimentation program for criticality safety professionals. In ; addition, this latter alternative would not result in a consolidation of these surplus materials and machines. It, therefore, does not meet the purpose and need for agency action and was eliminated from further analysis in the EA.

ENVIRONMENTAL EFFECTS: In as much as no new construction, operations, waște streams or emissions are anticipated under the proposed action, it is unlikely that the proposed action would have any adverse effects on environmental concerns. It is estimated that the proposed action would potentially have only a negligible effect on human health and on transportation issues. Neither the proposed action nor the no action alternative would pose a disproportionate adverse health or environmental effect on minority or low-income populations within an $80 \mathrm{~km}$ (50 mi) radius of the proposed site. Under the no action alternative, there is a potential for a minor amount of low-level radiological waste to be generated at Hanford, SNL/NM, ORNL and INEL. Because the proposed action is not expected to increase or decrease the environmental and health effects currently experienced at LACEF, no cumulative effects are anticipated. 
The analysis of accident scenarios indicates that the probability of an accident occurring and adversely affecting an exposed population is considered extremely unlikely.

No new environmental permits would be required to consolidate these surplus nuclear materials and machines at LACEF for the purposes of criticality experimentation and training.

PREDECISIONAL DRAFT REVIEW \& COMMENT: On April 12, 1996, DOE invited review and comment on the preapproval EA from the State of New Mexico and four American Indian Pueblos: Cochiti, Jemez, Santa Clara and San Ildefonso (i.e., four accord pueblos). On May 1 1996, DOE invited review and comment on the preapproval EA from the State of Washington and four American Indian tribes (Wanapum, Yakima, Nez Perce, Umatilla), located near the Hanford DOE Site, which potentially might be affected by shipments of low enriched uranium fuel rods from Hanford to LANL. In addition, DOE made the predecisional draft EA available to Los Alamos County and the general public at the same time $\because$. it was provided to the State of New Mexico and four accord pueblos by placing it in the Los Alamos National Laboratory Community Reading Room and the DOE Public Reading Room in Albuquerque. Also, local stakeholder groups were notified of the availability of the pre-decisional draft on April 16, 1996.

Comments were received from one party; the New Mexico Environment Department. This set of comments was addressed in the Final EA, and an individual response to the comments was prepared by LAAO and sent to the respondent. 
FOR FURTHER INFORMATION CONTACT: For further information on this proposal, this

Finding Of No Significant Impact (FONSI), or the DOE's National Environmental Policy Act (NEPA) review program concerning proposals at LANL, please contact:

Elizabeth Withers, NEPA Compliance Officer

Los Alamos Area Office

U.S. Department of Energy

528 35th Street

Los Alamos NM 87544

(505) 667-8690

Copies of the environmental assessment and this FONSI will be made available for public review at the Los Alamos National Laboratory Community Reading Room, 1450 Central Avenue, Suite 101, Los Alamos, New Mexico, 87544 at (505) 665-2127 or (800) 5432342. Copies will also be made available in the DOE Public Reading Room, located in the Atomic Museum, 20358, Wyoming Boulevard, Albuquerque, New Mexico, 87185 at (505) 845-6670.

FINDING: The United States Department of Energy finds that there would be no significant impact from proceeding with its proposal to consolidate certain nuclear materials and machines used for criticality experiments at LACEF, TA-18, LANL. DOE makes this Finding of No Significant Impact pursuant to the National Environmental Policy Act of 1969 [42 U.S.C. 4321 et seq.], the Council on Environmental Quality (CEQ.) regulations [40 CFR 1500] and the DOE NEPA regulations [10 CFR 1021]. Based on the environmental assessment that analyses the potential environmental effects that would be expected to occur if the DOE were to consolidate these surplus materials and machines at LACEF, the 
proposed action does not constitute a major federal action which would significantly affect the human environment within the meaning of NEPA. Therefore, no environmental impact statement is required for this proposal.

Signed in Los Alamos, New Mexico this $22^{n d}$ day of 1996.

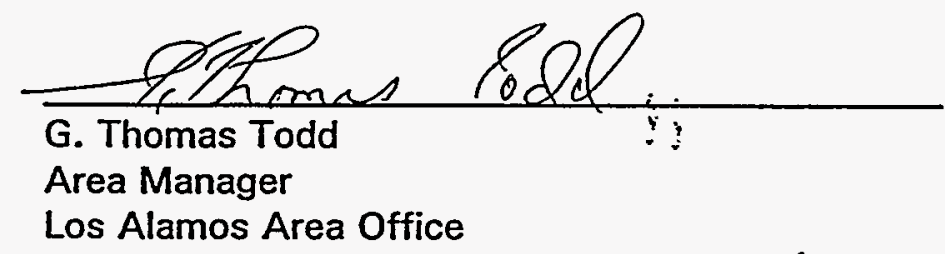




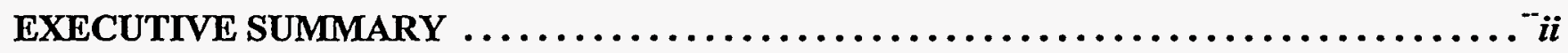

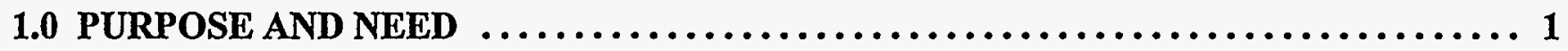

1.1 Background Information $\ldots \ldots \ldots \ldots \ldots \ldots \ldots \ldots \ldots \ldots \ldots \ldots \ldots \ldots \ldots, \ldots \ldots \ldots$

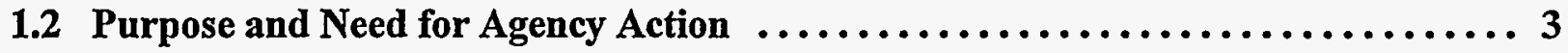

2.0 DESCRIPTION OF OPERATIONS AND ALTERNATIVES $\ldots \ldots \ldots \ldots \ldots \ldots \ldots \ldots 4$

2.1 Description of LACEF and Facility Operations $\ldots \ldots \ldots \ldots \ldots \ldots \ldots \ldots \ldots, 4$

2.2 Description of Surplus Critical Assemblies and Machines $\ldots \ldots \ldots \ldots \ldots \ldots \ldots .8$

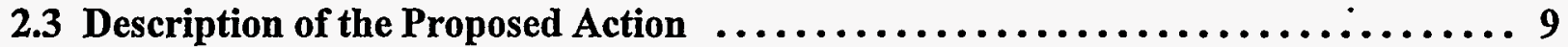

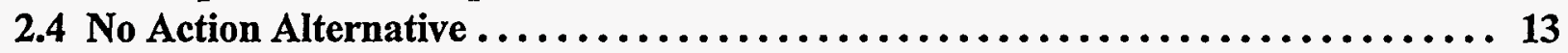

2.5 Alternatives Considered but Eliminated from Further Analysis ............ 13

2.6 Foreseeable Related and Future Actions.$\ldots \ldots \ldots \ldots \ldots \ldots \ldots \ldots \ldots \ldots \ldots \ldots$

3.0 AFFECTED ENVIRONMENT $\ldots \ldots \ldots \ldots \ldots \ldots \ldots \ldots \ldots \ldots \ldots \ldots \ldots \ldots \ldots \ldots \ldots$

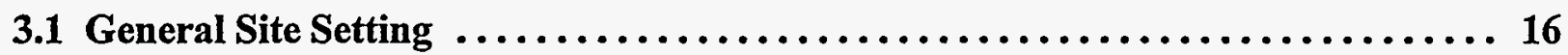

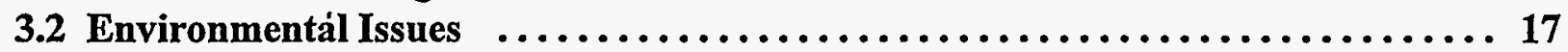

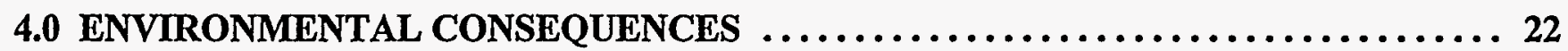

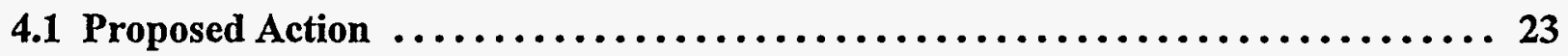

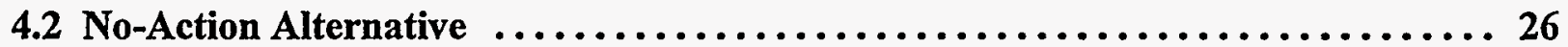

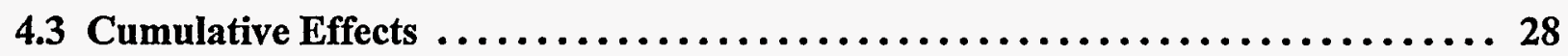

5.0 ABNORMAL EVENTS $\ldots \ldots \ldots \ldots \ldots \ldots \ldots \ldots \ldots \ldots \ldots \ldots \ldots \ldots \ldots \ldots \ldots \ldots . \ldots \ldots$

6.0 AGENCIES AND PERSONS CONSULTED $\ldots \ldots \ldots \ldots \ldots \ldots \ldots \ldots \ldots \ldots \ldots \ldots \ldots$

7.0 PERMIT REQUIREMENTS $\ldots \ldots \ldots \ldots \ldots \ldots \ldots \ldots \ldots \ldots \ldots \ldots \ldots \ldots \ldots \ldots \ldots, 32$

8.0 GLOSSARY OF TERMS AND ACRONYMS $\ldots \ldots \ldots \ldots \ldots \ldots \ldots \ldots \ldots \ldots \ldots \ldots, 33$

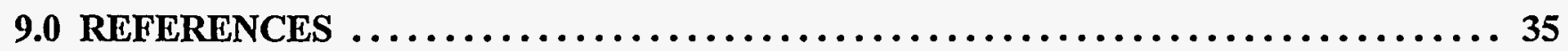

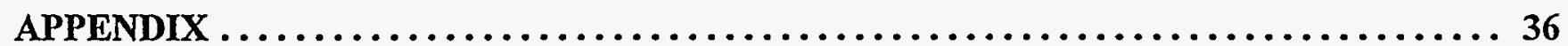




\section{Consolidation of Certain Materials and Machines for Nuclear Criticality Experiments and Training}

\section{EXECUTIVE SUMMARY}

In support of its assigned missions and because of the importance of avoiding nuclear criticality accidents, DOE has adopted a policy to reduce identifiable nuclear criticality safety risks and to protect the public, workers, government property and essential operations from the effects of a criticality accident. In support of this policy, the Los Alamos Critical Experiments Facility (LACEF) at the Los Alamos National Laboratory (LANL) Technical Area (TA) 18, provides a program of general purpose critical experiments. This program, the only remaining one of its kind in the United States, seeks to maintain a sound basis of information for:criticality control in those physical situations that DOE will encounter in handling and storing fissionable material in the future, and ensuring the presence of a community of individuals competent in practicing this control.

In the course of closing or reassignment of functions and responsibilities of various DOE facilities, certain nuclear materials and machines (mechanical systems designed to move special nuclear materials) used for criticality experiments are no longer needed to meet mission requirements at these facilities. Four facilities, the Hanford Site (Hanford) located in Richland, Washington; Sandia National Laboratory in Albuquerque, New Mexico (SNL/NM); Oak Ridge National Laboratory (ORNL) in Oak Ridge, Tennessee; and the Idaho National Engineering Laboratory (INEL) located in Idaho'Falls, Idaho, have recently identified certain nuclear materials and machines used for criticality experiments that they consider to be surplus to their needs. In addition, LANL currently has highly enriched uranium hemishells of graduated sizes (i.e. nesting shells) at LACEF that could also be used to conduct criticality experiments. DOE now has the opportunity to consolidate certain materials and machines at LACEF at LANL for continued use in its existing program of nuclear materials criticality training and experimentation, and manage these materials and machines in a manner that will maximize their utility.

The proposed action, to consolidate certain materials and machines at LACEF for the purposes of criticality experimentation and training, would have no effect on current activities conducted at LACEF. No new construction, operations, waste streams or emissions are anticipated under the proposed action. As a result, it is unlikely that the proposed action would have any adverse effects on environmental concerns. It is estimated that the proposed action would potentially have only a negligible effect on human health and on transportation issues. Neither the proposed action nor the no action alternative would pose a disproportionate adverse health or environmental effect on minority or low-income populations within an $80 \mathrm{~km}(50 \mathrm{mi})$ radius of the proposed site. Under the no action alternative, there is a potential for a minor amount of low level radiological waste to be generated at Hanford, SNL/NM, ORNL and INEL. Because the proposed action is not expected to increase or decrease the environmental and health effects currently experienced at LACEF, no cumulative effects are anticipated. The analysis of accident scenarios in the LACEF Safety Analysis Report (SAR) and in the Appendix to this Environmental Assessment (EA) indicates that the probability of an accident occurring and adversely affecting an exposed population is considered extremely unlikely. 


\section{Consolidation of Certain Materials and Machines for Nuclear Criticality Experiments and Training}

\subsection{PURPOSE AND NEED}

\subsection{Background Information}

Congress and the President have assigned the Department of Energy (DOE) a primary national security mission to provide for a safe, secure and reliable nuclear stockpile in the absence of explosive testing of nuclear weapons. A vital extension of this mission involves work in nonproliferation, counter proliferation, arms control verification, and intelligence support. Additionally, DOE has the primary mission to pursue research and technology development to enhance the long-term prospects for adequate energy supplies, more efficient use of energy and materials, and efficient technology products that minimize adverse environmental effects. DOE also has a major mission to contribute to the basic scientific foundation that supports its other mission areas and that contributes to the nation's scientific enterprise.

In support of its assigned missions and because of the importance of avoiding nuclear criticality ${ }^{1}$ accidents, DOE has adopted a policy to reduce identifiable nuclear criticality safety risks and to protect the public, workers, government property, essential operations and environmental resources from the effects of a criticality accident. In support of this policy, the Los Alamos Critical Experiments Facility (LACEF) at the Los Alamos National Laboratory (LANL) Technical Area (TA) 18, provides 'a program of general purpose critical experiments. This program, the only remaining one of its kind in the United States, seeks to maintain a sound basis of information for criticality control, covering the physical situations that will be encountered by DOE in handling and storing fissionable material in the future, and ensuring the presence of a community of individuals competent in practicing this control. An integral part of the program is to educate criticality control engineers by providing hands-on training. This unique training program is attended not only by DOE employees and contractors, but also by a wide variety of government and private sector scientists, as well as international scientists tasked with evaluating critical assemblies and special nuclear materials ${ }^{2}$ at nuclear facilities around the world.

On March 23, 1993, the Defense Nuclear Facilities Safety Board (the Board), a DOE oversight organization established under the Atomic Energy Act of 1954, approved and transmitted a recommendation to DOE (Recommendation 93-2, pursuant to 42 U.S.C. 2286a(5), Atomic Energy

\footnotetext{
${ }^{1}$ Nuclear criticality occurs when the atomic nuclei of certain kinds of radioactive materials are fissioned (physically split) into different kinds of radioactive materials as a result of collisions with neutrons. The splitting of the nuclei releases heat energy and radiation including more neutrons which can in turn split other fissionable nuclei. The reaction is considered to be critical when it reaches the point where it is self sustaining.

${ }^{2}$ Special nuclear material means plutonium, uranium-233, uranium enriched in the isotope 233 or in the isotope 235 , and any other material that the Nuclear Regulatory Commission determines to be special nuclear material..
}

Page 1

Final Environmental Assessment 


\section{Consolidation of Certain Materials and Machines for Nuclear Criticality Experiments and Training}

Act of 1954) that DOE continue its criticality experiment capability (Federal Register, Vol. 58, -No. 59, pages 16654-16655). In addition to citing the importance of avoiding criticality accidents, the Board stated its concern that the last remaining facility capable of general purpose criticality experimentation and criticality training could be terminated because of lack of funding. The U.S. Nuclear Regulatory Commission (NRC) also endorsed the Board's Recommendation 932 in a letter to the Secretary of Energy (Remick to O'Leary, July 21, 1993). The formal DOE response to the Board's Recommendation 93-2 was published for public notice and comment in the Federal Register, Friday, June 4, 1993 (Federal Register, Vol. 58, No. 106, pages 31699 31700). In its response, DOE accepted the Board's recommendation. As a:part of that response, DOE developed an implementation plan for Recommendation 93-2 in which it committed to continue special purpose criticality experiments within a general purpose criticality experiment facility.

Also integral to its assigned mission responsibilities in the post-Cold War era, DOE must determine the disposition of certain special nuclear materials and machines. Four facilities, the Hanford Site (Hanford) located in Richland, Washington; Sandia National Laboratory in Albuquerque, New Mexico (SNL/NM); Oak Ridge National Laboratory (ORNL) in Oak Ridge, Tennessee; and the Idaho National Engineering Laboratory (INEL) in Idaho Falls, Idaho, have recently identified certain special nuclear materials and machines that have no overriding programmatic mission at their current sites and are available to augment the DOE criticality experimentation and training program at LANL. In addition, LANL currently has highly enriched uranium hemishells of graduated sizes (i.e., nesting shells) at LACEF that could also be used to conduct criticality experiments and training.

The specific materials and machines identified are as follows: Hanford - 741 unirradiated Low Enriched Uranium (LEU) fuel rods; SNL/NM lightly irradiated and unirradiated Highly Enriched Uranium (HEU) reactor fuel; and ORNL - the Health Physics Research Reactor (HPRR) core which contains irradiated highly enriched uranium (HEU) reactor fuel. The INEL material includes surplus slightly irradiated plutonium plates. LEU reactor fuels are composed of uranium metal that contains less than 20 percent of the uranium isotope uranium-235. HEU reactor fuels are composed of uranium metal that contains 20 percent or greater of the uranium isotope uranium-235. These nuclear materials, machines and sources are representative of those that could be utilized for criticality experiments at LACEF.

DOE has identified two primary disposition options for consideration: it can either declare and manage the surplus materials and machines as waste or it may move the material and machines to other DOE facilities where they can be used for the same or other purposes.

Page 2

Final Environmental Assessment 


\section{Consolidation of Certain Materials and Machines for Nuclear Criticality Experiments and Training}

\subsection{Purpose and Need for Agency Action}

DOE has committed to continuing its on-going experimentation program of general purpose criticality experiments and to continuing to provide an education program for criticality safety professionals. LACEF is the last remaining operating facility in the United States capable of general purpose criticality experiments and criticality training. Criticality experiments at other DOE sites have been eliminated from their areas of responsibility in an effort to streamline the DOE complex and avoid expensive program duplication. The transfer of certain materials and machines now located at other DOE sites to LACEF will allow DOE to further its capability to provide a robust experimentation program in support of reducing nuclear criticality safety risks. 


\section{Consolidation of Certain Materials and Machines for Nuclear Criticality Experiments and Training}

\subsection{DESCRIPTION OF OPERATIONS AND ALTERNATIVES}

\subsection{Description of LACEF and Facility Operations}

As stated in Chapter 1.0, LACEF is located at LANL within TA-18 at Los Alamos, New Mexico. A location and vicinity map is shown on Figure 2-1. A schematic drawing of TA-18 showing the relative locations of the various building structures and the nearest public access is shown on Figure 2-2. LACEF is located in an arid canyon, approximately $5 \mathrm{~km}(3 \mathrm{mi})$ from the nearest residential area and $400 \mathrm{~m}(1,220 \mathrm{ft})$ from the closest occupied technical area (TA-54).

The principle function of LACEF is the design, construction, research, development, and application of criticality experiments. The facility is active in personnel training of criticality safety methods and techniques and in evaluating applications of radiation detection and nuclear instrumentation devices. To support this work is an inventory of fissionable material in various compositions, sizes, and shapes stored at TA-18. In addition, TA-18 supports a number of other national security programs.

LACEF currently houses a collection of machines of various types. Assemblies or critical assemblies ${ }^{3}$ consist of machines plus special nuclear material. The collection includes:

- $\quad$ Benchmark ${ }^{4}$ assemblies (well characterized and calculable radiation fields and configurations), identified as "Flattop" and "Big Ten"

- Assembly machines used to remotely assemble criticality experiments of varied configuration, identified as "Mars", "Venus", "Comet" and "Honeycomb"

- An assembly, known as "SHEBA", used to study criticality events for materials in solution

- Fast-burst assemblies for producing fast neutron pulses, known as "Godiva IV" and "Skua"

\footnotetext{
${ }^{3}$ Assemblies or critical assemblies are machines that contain special nuclear materials that can be brought to a critical state by manipulating the radioactive materials.

${ }^{4}$ Benchmark assemblies are assemblies with stable, definable configurations containing precisely known components. They can have interchangeable or adjustable components.
}

Page 4

Final Environmental Assessment 


\section{Consolidation of Certain Materials and Machines for Nuclear Criticality Experiments and Training}

Figure 2-1 Location of LANL and TA-18

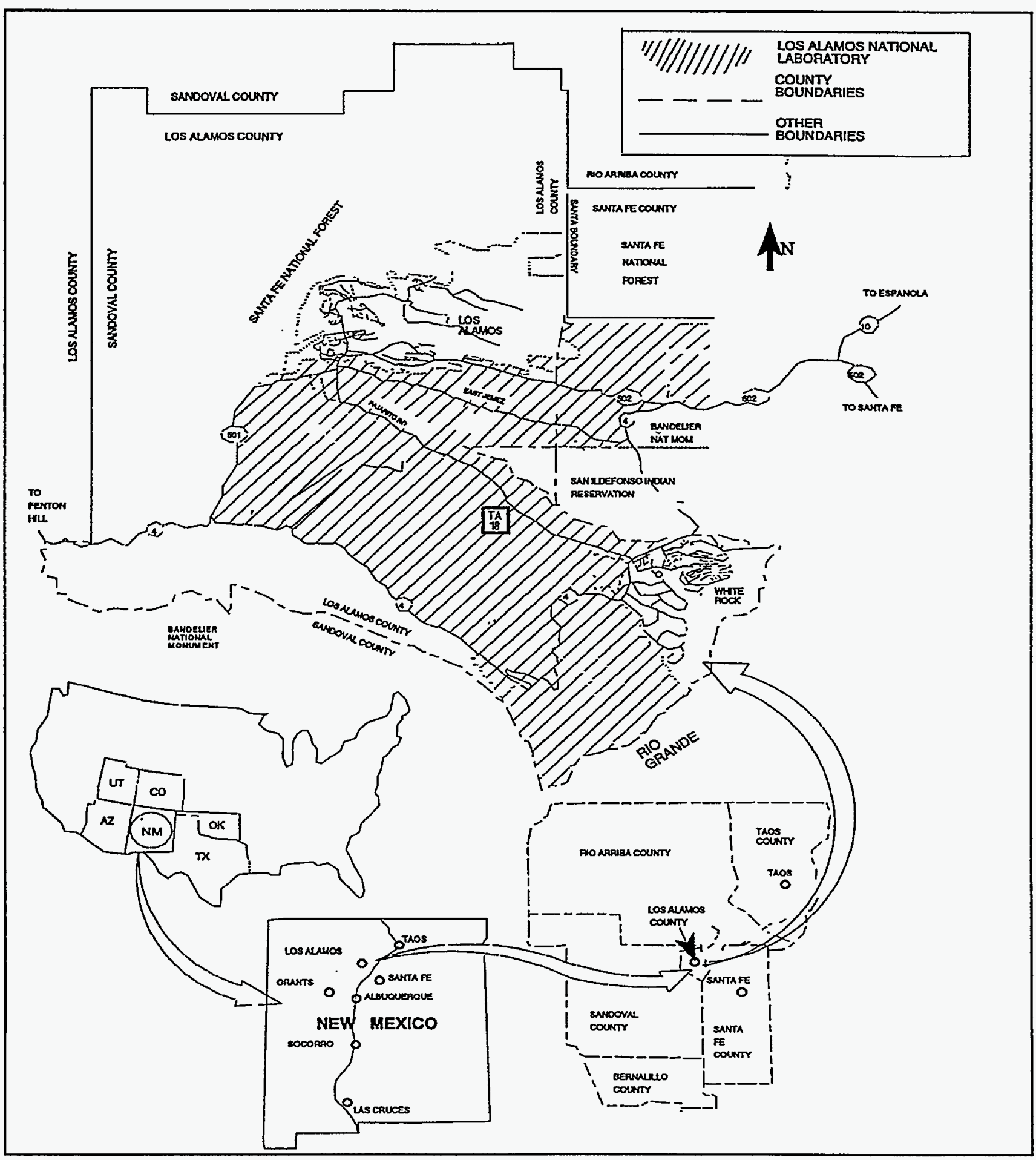

Page 5

Final Environmental Assessment 


\section{Consolidation of Certain Materials and Machines for Nuclear Criticality Experiments and Training}

Figure 2-2 Layout of the Buildings at the TA-18 Site

Map Not Drawn to Scale

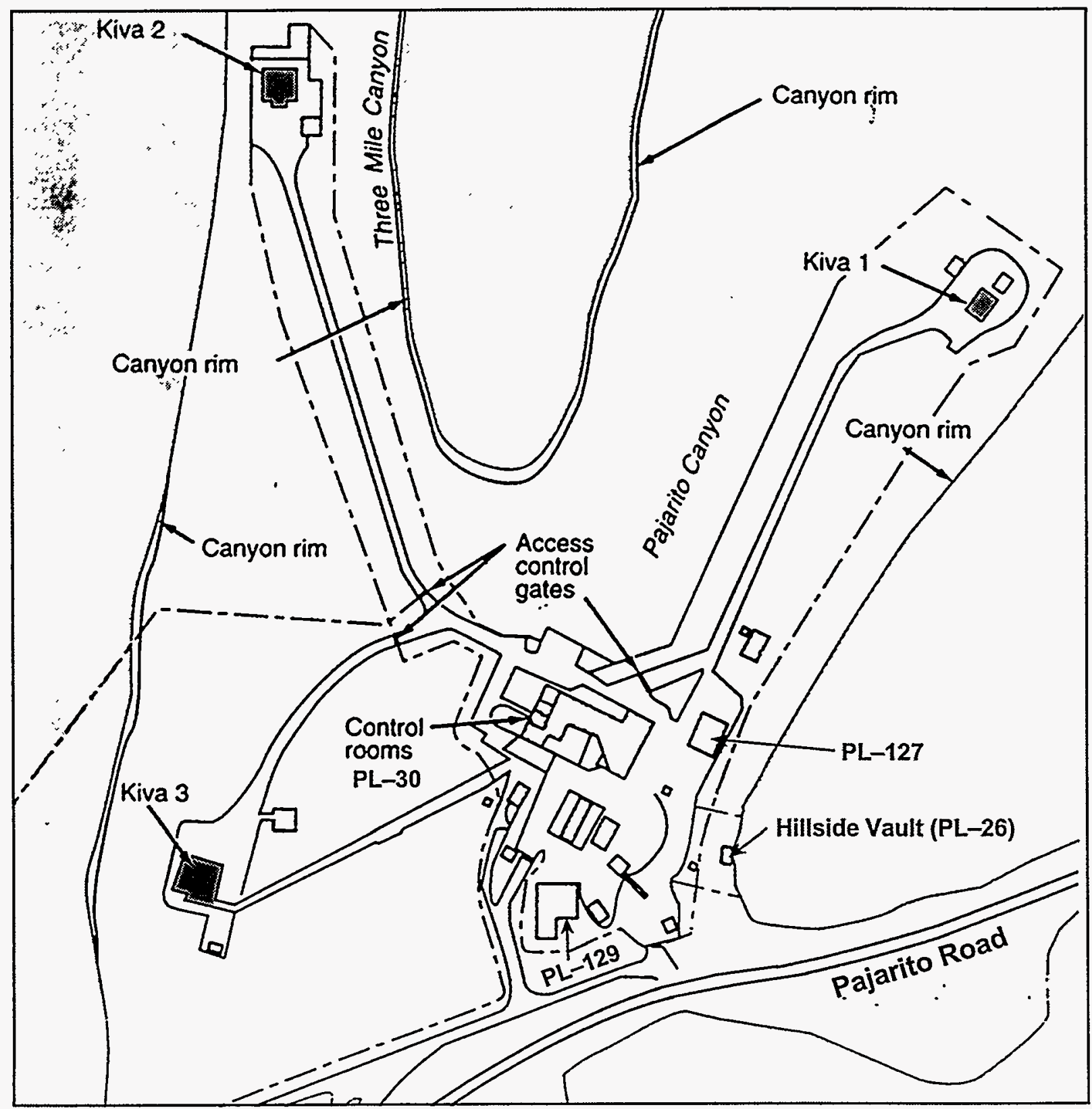

Page 6

Final Environmental Assessment 


\section{Consolidation of Certain Materials and Machines for Nuclear Criticality Experiments and Training}

LACEF consists of three remote-controlled laboratories commonly referred to as "kivas". Although the term "kiva" in the southwest pueblo culture refers to a community meeting structure, the kivas used at LANL have no pueblo cultural significance. The various materials used to support the operations of the critical assemblies are stored in the kivas. Storage conforms to the American National Standard, "Nuclear Criticality Safety in Operations with Fissionable Material Outside Reactors," ANSI/ANS-8.1-1983 (DOE, 1994).

The kivas are constructed of reinforced concrete and masonry block. Each kiva is surrounded by a posted radiological control area and a physical security barrier with automatic signals to forewarn personnel of impending operations. Access to the kivas, including the area immediately surrounding the kivas, is controlled in many ways such as through the use of pre-approved access lists, escort by site security personnel, a strictly imposed "buddy" system, administratively controlled key procedures, and LANL Standard Operating Procedures (SOPs). TA-18 is authorized to store special nuclear materials as a Category II nuclear facility (DOE-STD-1027-92). In accordance with the LACEF SAR (DOE, 1994), there are no limits on the amount of special nuclear materials that can be used at LACEF, but there are administrative limits on the amounts of materials that can be stored in the kivas at LACEF. An inventory of special nuclear materials is routinely performed.

Critical assembly operations are performed remotely from three separate but grouped control rooms located in the TA-18 main laboratory building (PL-30) at some distance from the kivas. Experiments are performed primarily inside of the kivas but can also be performed outside of the kivas for certain critical assemblies such as SHEBA and Godiva. The main laboratory building also houses the group management, operations staff, several support laboratories, and electronic assembly areas. Additional structures consist of the Hillside Vault (PL-26) that is also used for special nuclear material storage; Building PL-127, also known as the High Bay, which can be used as a special nuclear material access area; and Building PL-129 which is used for radiation detector calibration and development.

Basic critical assembly design and operational procedures have evolved over the 40 years LACEF has been in operation. Each critical assembly and criticality experiment machine is designed and operated in conformance with a set of design principles and operating limitations, including the requirement for remote final experiment assembly. The criteria for safe operations include requirements on the motion of control devices, the need to assure reproducible geometries, and the availability of independent redundant scram systems ${ }^{5}$. All assembly designs, experiments and operations are conducted within the scope of the LANL 1979 Site Wide Environmental Impact

\footnotetext{
${ }^{5}$ Scram systems refer to safety control systems that are used to terminate a criticality event by reducing the number of available neutrons or by altering the configuration of the mass of the special nuclear materials.
}

Page 7

Final Environmental Assessment 


\section{Consolidation of Certain Materials and Machines for Nuclear Criticality Experiments and Training}

Statement (DOE/EIS-0018) and the parameters authorized by the LACEF SAR (DOE, 1994), the LACEF Technical Specifications and the LACEF Quality Assurance Program for design review, safety classification, and quality management. Safety features are designed into each LACEF criticality experiment. Each criticality experiment has at least two independent safety mechanisms that can be scrammed automatically or manually and at least two automatic power-monitoring scram initiating instruments.

The current operations staff at TA-18 consists of approximately 12 personnel. Routine operations in support of the various research and development activities result in the performance of approximately 300 to 400 experiments a year. The testing of a critical assembly involves from two to six personnel depending upon the specific nature of the experiment being performed. Training classes are conducted approximately six times a year for a period of three to five days for each class. During training operations the class size consists of approximately 16 trainees. Trainees are always stationed at a remote location such as the control room (Figure 2-2) when criticality experiments are conducted. TA-18 personnel work directly with the critical assemblies and the fuel material during experiment set-up and take-down. During actual operation of the critical assemblies, the kiva is not accessible to personnel. The operations team is in the applicable kiva control room in the main laboratory building.

\subsection{Description of Currently Identified Surplus Critical Assemblies and Machines}

Hanford LEU Fuel Rods: Hanford is no longer operating any reactor facilities and has a surplus of 741 unirradiated LEU fuel rods. Although these fuel rods were originally intended for use as reactor fuel, they are no longer needed for this purpose. They can now be used to perform criticality experiments. The Hanford fuel rods are approximately $96.5 \mathrm{~cm}$ (38 in) in length and $0.13 \mathrm{~cm}(0.5 \mathrm{in})$ in diameter and consist of 4.3 percent enriched uranium oxide pellets encapsulated in aluminum. Each fuel rod contains about $0.92 \mathrm{~kg}(2.0 \mathrm{lb})$ of uranium. 'The LEU fuel rods are currently in storage at Hanford.

Critical Experiment Particle Bed Fuel Assembly: The Critical Experiment (CX) Particle Bed Fuel Assembly was designed and built at SNL/NM to operate as a benchmark assembly. Its purpose was to obtain experimental results, which could be used to benchmark reactor design computer codes, and to obtain results for conditions that cannot be accurately determined using computer codes. Experiments conducted at SNL/NM with the CX materials began in October 1989 but were terminated shortly thereafter due to loss of funding. These experiments left some of the fuel materials slightly irradiated. The CX assembly uses approximately $26 \mathrm{~kg} \mathrm{(57} \mathrm{lb)} \mathrm{of}$ enriched uranium as fuel. It is considered to be unique because of its physical form. The CX assembly is currently not in operation. The fuel is in storage at SNL/NM but the CX machinery and controls are in storage at TA-18 at LANL.

Page 8

Final Environmental Assessment 


\section{Consolidation of Certain Materials and Machines for Nuclear Criticality Experiments and Training}

Health Physics Research Reactor: Prior to its retirement in 1986, the HPRR had been operated at Oak Ridge for over two decades as a uniquely well characterized source of neutrons and gamma radiation for a myriad of radiation dosimetric ${ }^{6}$ studies. It was primarily used for dosimetric intercomparison studies and criticality accident dosimeter calibrations required by DOE Orders and policies. It was also used at the Nevada Test Site to simulate the radioactive yield of the first atomic bomb for retrospective dose calculations. The retired HPRR and its critical materials are currently in storage at the DOE Y-12 Plant, in Oak Ridge, Tennessee.

The HPRR consists of a critical assembly fabricated from enriched uranium: The assembly is designed for self-limiting critical burst operation. The reactor core consists of approximately 116 $\mathrm{kg}(255 \mathrm{lb})$ of uranium fuel material. The uranium fuel is 90 percent by weight uranium alloyed with 10 percent by weight molybdenum. In addition to the primary core, there are some replacement parts and specially made samples for core analysis.

Idaho National Engineering Laboratory Materials: These materials were originally used in criticality experiments at the Argonne National Laboratory West, Zero Power Research Reactor (ZPRR) facility at INEL. That facility is currently shut down with little reasonable chance that it would be reactivated. Approximately $100 \mathrm{~kg}(220 \mathrm{lb})$ of weapons grade plutonium has been declared surplus to the INEL needs and is, therefore, available for use in general criticality experiments. The material is in the form of plates that measure about $5.1 \mathrm{~cm}(2 \mathrm{in})$ wide by 20.3 $\mathrm{cm}(8 \mathrm{in})$ long by $0.3 \mathrm{~cm}(0.125 \mathrm{in})$ thick. Each plate weighs approximately $0.64 \mathrm{~kg}(1.4 \mathrm{lb})$ each. All plates are encased in stainless steel and are hermetically sealed. The plates are currently in storage at INEL.

Nesting Shells: Nesting shells are currently used in training exercises routinely conducted by the DOE Nuclear Emergency Search Team (NEST) at LANL. NEST training exercises require participants to locate hidden materials and do not involve criticality experiments. These nesting shells consist of a set of metal hemishells of graduated sizes constructed of HEU metal. There are a total of 80 shells weighing about $270 \mathrm{~kg}(594 \mathrm{lbs})$. They can be combined in various ways to construct radiation training devices and other HEU items. These shells are a unique set of resource materials within DOE. The nesting shells are currently in storage in LACEF.

\subsection{Description of the Proposed Action}

The proposed action consists of the shipment, storage, consolidation and use of surplus special nuclear materials and machines that would be used in support of the LACEF criticality

\footnotetext{
${ }^{6}$ Dosimetric pertains to the measurement of radiation doses. Dosimetry is the science of measuring radiation doses. A dosimeter is an instrument that measures radiation dose.
}

Page 9

Final Environmental Assessment 


\section{Consolidation of Certain Materials and Machines for Nuclear Criticality Experiments and Training}

experiments and training program at LANL. As stated, the available special nuclear materials añd machines include the LEU fuel rods at Hanford, the CX particle bed fuel at SNL/NM, the HPRR at ORNL, the plutonium plates at INEL and the nesting shells at LANL. These materials and machines would be packaged and transported by either DOE or commercial carrier from their current locations to LACEF (except for the CX machine and equipment and nesting shells currently stored at LACEF). The storage and use of these materials would take place in any or all of the three kivas located at LACEF. The primary use of these materials and machines would be to conduct criticality experiments and criticality training. No new construction would be required to support the proposed action. As stated in Section 2.1, no change in the anticipated annual number of criticality experiments or training classes conducted at the LACEF would occur. Instead, the materials and machines that are the subject of this assessment would be used to augment ongoing experiments and training programs. The proposed action would not change the TA-18 Category II nuclear facility status. No new type of operation or expansion of existing operations are planned at LACEF as a result of the proposed action. If any new type or expansion of operations is proposed in the future, additional National Environmental Policy Act (NEPA) documentation would be prepared.

The anticipated operational life of the proposed action is approximately 30 years. Following completion of the operational life of activities associated with the proposed action, the machines used to perform criticality experiments may require decontamination and decommissioning. The disposition of special nuclear materials used in the proposed action would also require evaluation at that time. Because of the long radiological half-life of the special nuclear materials used under the proposed action and the fact that the materials would not be considered to be spent nuclear materials, alternative uses for the special nuclear materials are highly likely. Additional NEPA reviews would be needed when it is time to decontaminate and decommission machines and equipment and to evaluate alternative uses for the special nuclear materials used under the proposed action.

Under the proposed action, routine LACEF criticality experiment procedures would be followed. Criticality experiment workers would be required to conduct routine inventories of special nuclear materials and set-up and take-down criticality experiments in the kivas. Workers would not be present in the kivas during experiments. They would be required to withdraw to remote locations such as the control room when the actual experiments are being conducted. It is estimated that between two to six involved personnel, including operators, radiation control technicians, and protective force (security), would be required per work shift to perform a criticality experiment, including experiment set-up and take-down. The average frequency for criticality experiments under the proposed action is anticipated to remain relatively constant.

Page 10

Final Environmental Assessment 


\section{Consolidation of Certain Materials and Machines for Nuclear Criticality Experiments and Training}

Specific details regarding each of the materials and machines being considered under the proposed action including packaging, transporting, storage and use, are provided below.

Hanford LEU Fuel Rods: Hanford declared as surplus 741 unirradiated fuel rods that would be utilized at LACEF in support of their criticality training mission. The fuel rods would be packed in aluminum cylinders, placed in U. S. Department of Transportation (DOT) authorized transportation containers, and shipped from Hanford to LANL, TA-18, by way of either a DOE or commercial carrier. The Hanford fuel rods would be transferred over the $2,000 \mathrm{~km}(1,200 \mathrm{mi})$ from the Hanford Site to LANL as a single shipment in DOT specification $6 \mathrm{M}$ containers. The fuel rods would be inspected upon arrival by LANL personnel and stored at LACEF in a rack designed to provide a criticality-safe configuration. The fuel would initially be stored within Kiva 1. However, all or part may be transferred to one of the other two kivas as needed over the life of the program. The total amount of uranium contained within the 741 fuel rods to be transferred from Hanford to LACEF is approximately $680 \mathrm{~kg}(1,500 \mathrm{lb})$. The LEU fuel rods would support ongoing criticality training at TA-18.

CX Particle Bed Fuel: The CX Particle Bed Fuel is currently in storage at SNL/NM. The supporting equipment and machinery are already in storage in LACEF. All three forms of the CX material would be shipped by SNL/NM in DOT specification $6 \mathrm{M}$ containers. The materials would be shipped by the DOE over public highways in special transport vehicles known as Safe Secure Trailers (SSTs). SSTs are specialized trailers used to safeguard special nuclear materials and other items to prevent unauthorized access. The CX fuel would be transported the $160 \mathrm{~km}(96 \mathrm{mi})$ from SNL/NM to LANL as a single shipment. The materials would be inspected upon arrival by LANL personnel and stored in a criticality-safe configuration within one of the three kivas at LACEF. The total amount of CX fuel that would be sent to LACEF would consist of $26 \mathrm{~kg}$ (57 lb) of uranium.

Health Physics Research Reactor: The HPRR and its special nuclear material, which are currently in storage at the Y-12 Plant in Oak Ridge, would be inspected and packaged in DOT specification $6 \mathrm{M}$ shipping containers. The HPRR and it associated special nuclear materials and equipment would be shipped by DOE SSTs to LANL as weapons grade material. The HPRR core would be transported the $2,300 \mathrm{~km}(1,380 \mathrm{mi})$ from Oak Ridge National Laboratory to LANL as a single shipment of approximately 20 DOT Specification $6 \mathrm{M}$ packages or containers. The materials would be inspected upon arrival and initially placed in a criticality safe storage configuration within one of the kivas. About $246 \mathrm{~kg}(541 \mathrm{lb})$ of uranium fuel material would require storage at LACEF. Re-assembly of the HPRR would then be accomplished to support DOE programmatic needs. Under the proposed action, personnel at LACEF would use the HPRR to perform the calibration of criticality accident dosimeters and validation testing of criticality alarms. Some of these measurements may require operation of the HPRR outside of the kivas.

Page 11

Final Environmental Assessment 


\section{Consolidation of Certain Materials and Machines for Nuclear Criticality Experiments and Training}

Idaho National Engineering Laboratory: The surplus weapons grade plutonium in storage at INEL, would be inspected and packaged in DOT authorized shipping containers. The INEL materials would be shipped by DOE SSTs to LANL as weapons grade material. The INEL materials would be transported the $1363 \mathrm{~km}$ ( $818 \mathrm{mi}$ ) from Idaho National Engineering Laboratory to LANL as a single shipment of one to two DOT Specification $6 \mathrm{M}$ packages or containers. The materials would be inspected upon arrival and initially placed in a criticality safe storage configuration within one of the kivas. This $100 \mathrm{~kg}(220 \mathrm{lb})$ of plutonium would be stored at LACEF. Under the proposed action, the INEL plutonium would be used for conducting experiments that examine the criticality behavior of plutonium.

Nesting shells: The nesting shells are currently in criticality safe storage at LACEF. No additional packaging or transporting of these materials would be required. The nesting shells are currently used for NEST training. This use would not be affected by potential activities anticipated under the proposed action. Under the proposed action, the nested shells would be used for general purpose criticality experiments and training at LACEF.

Under the proposed action, the DOE would achieve the following objectives:

- Reduce the probability of criticality accidents by maintaining a current basis of information for criticality control and a community of competent individuals.

- Maximize the utility of special nuclear materials, research tools and equipment from DOE facilities that are surplus at their current sites but which would augment criticality experimentation and training capabilities at LANL.

- Fulfill the Board's recommendation that DOE support its criticality facilities' infrastructure by maintaining a well trained and qualified staff and a sufficient amount of special nuclear material in a variety of forms.

- Support the validation and calibration of new nuclear criticality monitors and alarm systems prior to their use.

- $\quad$ Reduce ongoing storage costs by consolidating these materials at one location where they can support programmatic missions.

- Preserve unique national assets and eliminate or reduce the appreciable costs of replacing these resources should future needs arise for these materials.

Page 12

Final Environmental Assessment 


\section{Consolidation of Certain Materials and Machines for Nuclear Criticality Experiments and Training}

\subsection{No Action Alternative}

The no action alternative evaluates the programmatic and environmental effects of not packaging and transporting these materials to LANL and not receiving, storing and using these materials at TA-18. If the materials are not transported to LANL, it is anticipated that they would remain at their current locations (i.e. Hanford, SNL/NM, ORNL and INEL) until another site was found that could use the materials for other purposes or until the materials were declared a waste. The nested shells that are currently at LACEF would continue to be used for NEST training.

Alternative DOE sites that could use the materials would be required to have special nuclear material storage vaults to house the surplus materials and machines. Some materials, such as the Hanford LEU fuel rods, could be sold or donated to commercial users. Because of anticipated and on-going changes to DOE missions and facilities at each of the three sites, it is not anticipated that these sites would again perform criticality-related work with these materials. No other DOE site, except LANL, is expected to be able to perform the criticality experiments and training mission. Under the no action alternative, criticality experiments and training would continue to occur at LACEF using existing materials and machines. However, some types of experimentation and training that would be unique to the surplus materials and machines could not be done. This could affect DOE's ability to study various criticality scenarios and to train current and new DOE employees, other federal employees and members of national and international nuclear regulatory agencies. It also would affect DOE's ability to perform certain types of calibration testing for criticality monitors and alarm systems.

The no action alternative provides an environmental baseline to compare to the potential effects of the proposed action. Because this alternative would not enhance the criticality training and experimentation capability at LACEF, the no action alternative does not meet DOE's purpose and need for action. However, consistent with the Council on Environmental Quality and DOE NEPA regulations ( 40 CFR 1500 and 10 CFR 1021, respectively), this alternative is analyzed for comparison of potential effects with those of the proposed action.

\subsection{Alternatives Considered but Eliminated from Further Analysis}

Several alternatives were considered but eliminated from further analysis because they do not reasonably meet the purpose and need. Contributing to their inability to address the purpose and need were conflicts at potential sites with changing DOE programmatic missions from weapons work to environmental cleanup. In addition to mission changes, some facilities lacked adequate support facilities to conduct experiments and training as well as storage vaults for special nuclear

materials. Using these materials and machines at widely separated locations would continue to pose some transportation risk and would not improve or consolidate operations associated with the

Page 13

Final Environmental Assessment 


\section{Consolidation of Certain Materials and Machines for Nuclear Criticality Experiments and Training}

DOE criticality experiments and training program. Simply receiving and storing these materials ät alternative sites, without conducting experiments or training restricts the DOE's ability to efficiently consolidate and conduct criticality experiments and to meet its programmatic responsibilities. These limitations preclude the following options from being reasonable alternatives to the proposed action. These alternatives and their limitations in meeting the purpose and need are described in the following paragraphs.

\subsubsection{Conduct Operations at an Alternative DOE or LANL Site}

This alternative considers conducting general purpose criticality experiments and criticality training at an alternative DOE or LANL site. The special nuclear materials and machines used at Hanford, SNL/NM, ORNL and INEL can no longer be used at their current locations because of programmatic changes that have eliminated the supporting infrastructure required for their operation. In order to resume these operations at Hanford, SNL/NM, ORNL or INEL, this infrastructure would have to be recreated. No other DOE facilities have conducted general purpose criticality experiments or training on a routine basis. In addition, no other location at LANL has ever conducted these kinds of experiments or training on a routine basis. It would require the construction of new facilities, similar to existing kivas with remote control rooms, and the establishment of a supporting infrastructure, (such as exclusion areas and security access controls) to ensure safe and efficient operation at an alternative location. Currently LACEF is the only DOE facility with the infrastructure required to conduct general purpose criticality experiments and training safely and to store the requisite special nuclear materials on a routine basis. Fast-burst critical assembly facilities are in operation at two DOD sites (i.e. White Sands Missile Range, NM and Aberdeen Proving Ground, MD) and at SNL/NM, but these facilities are very specific to the nature of the testing performed and are not able to readily accept all of the special nuclear materials and machines addressed under the proposed action. In addition, these locations are not equipped to support the needs of general purpose criticality experiments and training as recommended by the Board and supported by the NRC. Since there are no alternative sites that could perform general purpose criticality experiments and support a criticality training program, this alternative does not meet the purpose and need for agency action addressed in Section 1.2. This alternative has been eliminated from further analysis in this EA.

\subsubsection{Receive and Store These Materials at LANL, or an Alternative DOE Site but Do Not Use Them For Conducting Experiments or Training}

The possibility of storing these materials at LANL or an alternative DOE site without the intent of using them to conduct general purpose criticality experiments or training is feasible. A number of DOE sites have the capability to safely receive and store special nuclear materials, particularly plutonium. This would enable the INEL materials to be stored at various alternative locations.

Page 14

Final Environmental Assessment 


\section{Consolidation of Certain Materials and Machines for Nuclear Criticality Experiments and Training}

Considering that the special nuclear material of concern at Hanford, SNL/NM and ORNL is -uranium, the most likely alternate would be to ship the material to the Y-12 Plant at Oak Ridge for storage. Only the CX and the Hanford materials would require shipment. As stated, the HPRR is currently at ORNL. No new storage facilities would be needed to house these materials. However, this alternative does not support the DOE's commitment to continue its on-going experimentation program of general purpose criticality experiments and to provide for an education program for criticality safety professionals. In addition, this action would not result in a consolidation of these special nuclear materials and machines to achieve mission purposes. This alternative does not meet the purpose and need for agency action addressed in Section 1.2, it has therefore, been eliminated from any further analysis in this EA.

\subsection{Foreseeable Related and Future Actions}

The updated LANL Site-Wide Environmental Impact Statement (SWEIS), currently being prepared, will address cumulative effects for all LANL operations including those that could result from a decision made regarding the proposed action under this EA. A Record of Decision (ROD) for the LANL SWEIS is expected in the spring of 1997. Delaying the proposed project until the LANL SWEIS is completed could result in unacceptable delays in obtaining the surplus special nuclear materials and criticality machinery needed to support the DOE criticality experiments and training program. DOE had stated its intention in the LANL SWEIS Notice of Intent (Federal Register, Vol. 60, No. 92, pages 25697-25703) to conduct the NEPA analysis for the receipt, storage and use of special nuclear materials for criticality experiments at LANL independent of the LANL SWEIS. DOE had determined that the NEPA analysis of the proposed action should continue in parallel with the LANL SWEIS process. This decision was based on the determination that the proposed action would neither influence nor be influenced by the updated LANL SWEIS.

DOE gave public notice of its intent to prepare the Stockpile Stewardship and Management (SSM) Programmatic Environmental Impact Statement (PEIS) on June 14, 1995. DOE anticipates that the ROD for this PEIS, scheduled for fall, 1996, will identify the future missions of the stockpile stewardship and management program and determine the configuration of the nuclear weapons complex needed for stockpile stewardship and management missions. While LACEF has in the past and is expected to continue to support both stockpile stewardship and management activities, activities associated with the proposed action would neither influence nor be influenced by programmatic decisions stemming from the PEIS. If DOE decides, after completing the SSM PEIS, to reassign mission responsibilities to LANL that would require a greater capability and capacity than is currently provided by LACEF, DOE would perform additional NEPA reviews.

Page 15

Final Environmental Assessment 


\section{Consolidation of Certain Materials and Machines for Nuclear Criticality Experiments and Training}

\subsection{AFFECTED ENVIRONMENT}

This section characterizes pertinent information regarding the general environmental setting of LANL and the immediate TA-18 site vicinity. More extensive information describing the LANL environment is presented in the annual LANL Environmental Surveillance Report (LANL 1995) as well as the LANL 1979 Site-Wide Environmental Impact Statement (DOE/EIS-0018).

\subsection{General Site Setting}

LANL is located on $111 \mathrm{~km}^{2}\left(43 \mathrm{mi}^{2}\right)$ of land in Los Alamos County in north-central New Mexico, approximately $100 \mathrm{~km}(60 \mathrm{mi})$ north-northeast of Albuquerque, $40 \mathrm{~km}(25 \mathrm{mi})$ northwest of Santa Fe, and $30 \mathrm{~km}$ (20 mi) southwest of Espanola. It is situated on the Pajarito Plateau, a series of mesas and canyons, at an elevation of $2,200 \mathrm{~m}(7,200 \mathrm{ft})$ above sea level. LANL borders San Ildefonso Pueblo to the east and Bandelier National Monument to the south (Figure 2-1). LANL is divided into 30 active TAs for administrative purposes. The population within the three counties (Los Alamos, Rio Arriba, and Santa Fe) surrounding LANL is just over 152,000 and is projected to exceed 250,000 by the year 2010 (Bureau of the Census, 1994). Los Alamos has a semiarid, temperate mountain climate. Average annual precipitation is about $45 \mathrm{~cm}$ (18 in). Typical winds consist of light westerly surface winds. However, surface winds at LANL often vary dramatically with time-of-day and, because of complex surface terrain, with location. In general, the predominant wind direction is from the southwest to the northeast.

Water occurs as on-site surface waters, shallow. ground water, and as the main aquifer underlying LANL. The on-site surface and shallow ground waters are not a source of municipal, industrial, or agricultural supply. TA-18 is located primarily in Pajarito Canyon with Kiva 2 located in Three Mile Canyon. Pajarito Canyon has a large drainage area that originates on the slopes of the Jemez Mountains to the west of the Pajarito Plateau. The stream in this canyon is perennial on the slopes of the mountains across the western half of the plateau and ephemeral across the eastern half of the plateau where it passes through TA-18 toward the Rio Grande. Three Mile Canyon contains only an ephemeral stream as it passes through TA-18. Groundwater occurs in the canyons in shallow alluvium in the stream channel and is highly seasonal.

Along the canyon floors, TA-18 is a level, open grassy area. The canyon walls support a pinon pine/juniper community. The animal population consists primarily of birds, field rodents, deer and elk. No threatened or endangered species are known to inhabit the TA-18 site and there is no designated critical habitat. Soils at the site are primarily sandy clays. They are well-drained and are nearly level to moderately sloping. These soils have slow to medium run-off and a moderate erosion hazard. The site is located in a floodplain but it contains no wetlands. The TA-18 site contains historical or archaeological sites that are located primarily along the canyon walls.

Page 16

Final Environmental Assessment 


\section{Consolidation of Certain Materials and Machines for Nuclear Criticality Experiments and Training}

\subsection{Environmental Issues}

Table 3-1 lists potential environmental issues and whether or not they are analyzed in this EA.

Table 3-1. Potential Environmental Issues

\begin{tabular}{|c|c|c|}
\hline Potential Issue & Applicability & Described in Section \\
\hline Human Health & & $3.2 ! 1$ \\
\hline Transportation & & 3.2 .2 \\
\hline Waste Management & & 3.2 .3 \\
\hline Environmental Justice & & 3.2 .4 \\
\hline Water Quality & NA - no change in water quality & \\
\hline Threatened or Endangered Species & NA - none present in TA-18 & \\
\hline Wetlands & NA - none present in TA-18 & \\
\hline Cultural Resources & NA - no construction activities & \\
\hline Environmental Restoration & NA - no clean-up required & \\
\hline Socioeconomics & $\begin{array}{l}\text { NA - no change in regional } \\
\text { socioeconomic conditions }\end{array}$ & \\
\hline Floodplains & $\begin{array}{l}\text { NA - none of the alternatives would } \\
\text { affect a floodplain }\end{array}$ & \\
\hline Wild horses and burros & NA - none present at LANL & \\
\hline $\begin{array}{l}\text { Wildlife (including non T\&E, } \\
\text { migratory birds, fish) }\end{array}$ & $\begin{array}{l}\text { NA - operations in existing building } \\
\text { or already disturbed areas }\end{array}$ & \\
\hline Noise & $\begin{array}{l}\text { NA - in an industrial developed area } \\
\text { /inside existing building }\end{array}$ & \\
\hline Prime farmland & NA - none present at LANL & \\
\hline Wild and scenic rivers & $\begin{array}{l}\text { NA - none present at LANL or } \\
\text { bordering LANL }\end{array}$ & \\
\hline Geology/Seismology/Soils & $\begin{array}{l}\text { NA - in existing building or } \\
\text { developed areas }\end{array}$ & \\
\hline 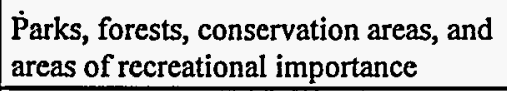 & $\begin{array}{l}\text { NA - operations in existing building } \\
\text { or developed areas }\end{array}$ & \\
\hline Land Use & $\begin{array}{l}\text { NA - no change from current } \\
\text { industrial use }\end{array}$ & \\
\hline
\end{tabular}




\section{Consolidation of Certain Materials and Machines for Nuclear Criticality Experiments and Training}

\subsubsection{Human Health}

The radiation environment at LANL and the surrounding communities is continuously monitored and characterized. The results are reported in the Annual LANL Environmental Surveillance Report (LANL 1995). Air is routinely sampled at locations on LANL property, along the DOE boundary perimeter, and in more distant areas that serve as regional background stations. Atmospheric concentrations of radioactive nuclides (radionuclides) are measured to estimate internal radiation doses. Thermoluminescent dosimeters (TLDs) are used to determine external penetrating radiation doses in the area. Background dose estimates are subtracted from the measured values to determine the effective dose equivalents ${ }^{7}$ (EDE) to the public at or outside the site boundary and at the nearest residence. LANL radiation worker exposures are similarly determined from personnel monitoring and personnel TLD badge data.

The radiation environment at LANL consists of both (1) natural background radiation and induced background levels of radioactivity at LANL and the surrounding community, and (2) the worker's radiation environment within the LACEF. All individuals are subject to some irradiation even though they may not work with radioactive substances. The annual average EDE from background and induced radiation for 1993 to nearby residents in Los Alamos and White Rock was $342 \mathrm{mrem}$ and $327 \mathrm{mrem}$, respectively (LANL 1995). This dose is a compilation of doses from all principle exposure pathways including radon gas ( 50.2 percent), cosmic and terrestrial sources (25.6 percent), self irradiation (10.0 percent), medical and dental x-rays (13.3 percent) and LANL operations ( 0.8 percent). The maximum annual dose to a potentially exposed member of the public from LANL operations is estimated to be approximately $3.1 \mathrm{mrem}$. The DOE's public dose limit is $100 \mathrm{mrem} / \mathrm{yr}$ EDE received from all pathways. Tables 3-2 and 3-3 summarize the various estimated annual exposures to LANL workers and to the public associated with LANL operations during 1993.

From these data, estimates of the human risk of developing excess fatal cancers (i.e. cancer mortality above and beyond the background incidence rate of 20 percent or 1 in 5), from the radiation environment are made based on currently accepted mathematical models (ICRP,1991) that estimate radiation risk. These risk estimates predict the chance, or probability, of excess cancer fatalities. These values are compared with the risks expected to be caused by the proposed action, forming the basis for the human health effects described in Chapter 4.0.

\footnotetext{
${ }^{7}$ Effective dose equivalent is a term for the estimated radiation dose to the whole body that would result from a dose to any one or more body organs.
}

Page 18

Final Environmental Assessment 


\section{Consolidation of Certain Materials and Machines for Nuclear Criticality Experiments and Training}

Table 3-2. Summary of Annual Effective Dose Equivalents (EDE) Attributable to 1993 LANL Operations

\begin{tabular}{|c|c|c|c|c|}
\hline & $\begin{array}{c}\text { Maximum } \\
\text { Dose to an } \\
\text { Individual }^{\mathrm{a}, \mathrm{b}}\end{array}$ & \multicolumn{2}{|c|}{$\begin{array}{l}\text { Average Dose to } \\
\text { Nearby Residents }\end{array}$} & $\begin{array}{c}\text { Collective Dose to } \\
\text { Population } \\
\text { within } 80 \mathrm{~km} \text { of } \\
\text { Laboratory }\end{array}$ \\
\hline & & Los Alamos & White Rock & \\
\hline LANL Dose & 3.1 mrem & $0.15 \mathrm{mrem}$ & 0.03 mrem & 3 person-rem \\
\hline Background Dose & 342 mrem & 342 mrem & 327 mrem & $\begin{array}{l}72,000 \text { person- } \\
\text { rem }\end{array}$ \\
\hline DOE Public Dose Limit & 100 mrem & --- & - & ---- \\
\hline
\end{tabular}

"Maximum dose to an individual is the dose to any individual at or outside the Laboratory where the highest dose rate occurs (i.e. residence north of TA-53). LANL calculations take into account occupancy (the fraction of time a person is actually at that location), self-shielding, and shielding by buildings. The EPA method for calculating EDE does not allow for shielding and occupancy factors. Using the EPA methodology, the EDE for 1993 was 5.7 mrem, which is in compliance with EPA standards of $10 \mathrm{mrem} / \mathrm{year}$ through the air pathway.

'Doses are reported at the $95 \%$ confidence level.

Source: LANL 1995, p. 3.

Table 3-3. 1995 Average Occupational Exposure, EDE, for TA-18 Los Alamos Criticality Experimentation Facility

\begin{tabular}{||l|c|}
\hline \multicolumn{1}{|c|}{ Dose Source } & Dose (mrem/year) \\
\hline \hline Average External Dose to all TA-18 Workers & 10 \\
\hline Background Radiation Exposure & 342 \\
\hline DOE Occupational Exposure Limit & 5,000 \\
\hline $\begin{array}{l}\text { DOE Administrative Control Level/Whole } \\
\text { Body }\end{array}$ & 2,000 \\
\hline
\end{tabular}

Source: Personal communications with John Voltin, ESH-12 Dose Records, February 16, 1996.

Ongoing criticality experiments and operations at LANL are conducted according to strict guidelines established by existing LANL SOPs. Under these SOPs, engineering and administrative controls are implemented to minimize worker and public exposure to radiation. For the purpose of evaluating hazards to workers or the public, radiation is generally considered to be either an internal or external hazard in terms of how it affects the human body. Alpha and most 


\section{Consolidation of Certain Materials and Machines for Nuclear Criticality Experiments and Training}

beta particle radiation is considered to be an internal hazard. That is, it must be taken into the -body to cause a dose. Alpha particles and most beta particles are unable to penetrate human skin. In contrast, radiation types such as gamma-rays or neutron particles are easily able to penetrate skin and are considered to be external hazards. The types of radiation associated with criticality experimentation are primarily gamma-rays and neutron particles emitted at the time the radioactive atoms split or fission, gamma-rays and beta-emitting radionuclides emitted by fission products, and gamma-rays and alpha particles associated with uranium-235.

Exposure to radiation is closely monitored under the implementation of existing health and safety requirements for maintaining worker exposure to As Low As Reasonably Achievable (ALARA) levels, but not to exceed the DOE limit of 5 rem per year. The current LANL ALARA goal for maximum worker dose is 2 rem per year. Radiation protection requirements for workers at DOE facilities are set forth in the Code of Federal Regulations at 10 CFR 835.

\subsubsection{Transportation and Storage of Special Nuclear Materials}

Radioactive materials can be shipped to LANL by either commercial or DOE carriers. The DOE transports special nuclear materials by SST. Both the DOE and commercial carriers are required to transport radioactive materials in accordance with U.S. Department of Transportation (DOT) regulations (49 CFR 179) and NRC regulations (10 CFR 71). Packages used to transport radioactive materials are designed to limit personnel exposure to radiation under normal conditions and to limit the probability of an accidental release. Radioactive materials are transported over public roads that run through or around the LANL facility. Occasionally, roads in Los Alamos County are closed to the public to facilitate the movement of radioactive material. DOE has the option to restrict traffic on LANL roads and exercises this option during the movement of radioactive material which meet certain criteria for road closures.

Any radioactive material shipped to TA-18 is used, handled, and stored according to LANL SOPs and other administrative controls. Special nuclear materials are stored in any one of the three kiva storage vaults. Engineering controls, such as interlocks, safety gates, exclusion fences, and closed-circuit TV, are utilized to reduce personnel radiation exposures. Administrative controls, such as radiological postings and radiation work permits are also in effect for the handling and transportation of these radioactive materials at TA-18. Any radiation exposures incurred from this material is maintained at ALARA levels.

\subsubsection{Waste Management}

Low-level radioactive wastes from LACEF are disposed of at the LANL low-level radioactive solid waste disposal area at TA-54. Non-contaminated solid wastes (e.g. office trash) are taken to

Page 20

Final Environmental Assessment 


\section{Consolidation of Certain Materials and Machines for Nuclear Criticality Experiments and Training}

the Los Alamos County Landfill for disposal. Sewage from TA-18 is sent to the LANL sanitary" sewer system. No RCRA-hazardous or mixed wastes (i.e. radioactive and hazardous) are routinely generated at LACEF.

\subsubsection{Environmental Justice}

Under Presidential Executive Order 12898, federal agencies are responsible for identifying and addressing the possibility of disproportionately adverse health and socioeconomic impacts of proposed actions on minority (all people of color, exclusive of white non-Hispanics) and low-income (household incomes less than $\$ 15,000$ per year) populations. DOE is in the process of finalizing procedures for implementing the Executive Order. The manner in which. environmental justice issues should be addressed in an environmental assessment is expected to be addressed in the procedures. The analysis of environmental justice in this EA is not intended to establish the direction of DOE's future procedures implementing the Executive Order.

Within an $80 \mathrm{~km}(50 \mathrm{mi})$ radius of the TA-18 site, about 54 percent of the population is of a minority status. In terms of low-income populations, 24 percent of the households have annual incomes below $\$ 15,000$. Los Alamos County is approximately 14 percent minority (the percentage of non-whites, including Hispanics, defined by the US Census) and has a median family income of $\$ 60,798$ (1990 US Census, in 1989 dollars). Los Alamos County, which would be most directly affected by the proposed action, has a higher median family income and a much lower percentage of minority residents than the four surrounding counties.

The proposed action is not expected to have any adverse effects on off-site populations. Although populations that are subject to environmental justice considerations are present within $80 \mathrm{~km}$ (50 mi) of LANL, activities associated with the proposed action would not disproportionately affect low-income, minority, or Native American populations. Therefore, no adverse effects would be expected to populations subject to environmental justice considerations.

Page 21

Final Environmental Assessment 


\section{Consolidation of Certain Materials and Machines for Nuclear Criticality Experiments and Training}

\subsection{ENVIRONMENTAL CONSEQUENCES}

The environmental consequences of receiving and storing special nuclear materials from other DOE facilities and using these materials to conduct criticality experiments at TA-18 are addressed in detail in this chapter with an analysis of accident conditions in Chapter 5.0. A comparison of environmental effects resulting from the proposed action and the current or anticipated future conditions under the no action alternative is presented in Table 4-1. As stated in Section 2.3, the proposed action would have little effect on current activities being conducted at LACEF. As a result of this, it is unlikely that the proposed action would have any adverse effects on most environmental concerns (see Section 3.2). It is estimated that the proposed action would only have the potential to have an effect on human health and on transportation issues. Neither the proposed action nor the no action alternative would pose a disproportionate adverse health or environmental effect on minority or low-income populations within an $80 \mathrm{~km}(50 \mathrm{mi})$ radius of the proposed site. Under the no action alternative, there is a potential for a minor amount of low level radiological waste to be generated at Hanford, SNL/NM, ORNL and INEL. No other environmental issues have been evaluated in this chapter.

Table 4-1. Comparison of Potential Environmental Effects

\begin{tabular}{|c|l|l||}
\hline Issue & \multicolumn{1}{|c|}{ Proposed Action } & \multicolumn{1}{|c|}{ No Action Alternative } \\
\hline \hline Human Health & $\begin{array}{l}\text { No adverse health risk to workers, co- } \\
\text { located workers or the public. }\end{array}$ & No change. \\
\hline Transportation & $\begin{array}{l}\text { Transport of radioactive materiais to } \\
\text { LANL results in negligible dose to the } \\
\text { public and to truck crews. }\end{array}$ & $\begin{array}{l}\text { No transport of these materials to LANL and no } \\
\text { corresponding dose to the public or truck crews. } \\
\text { Materials may be transported to an alternative } \\
\text { site for storage or disposal. }\end{array}$ \\
\hline Waste Management & No effects & $\begin{array}{l}\text { Potential for 5 cubic meters (7 cubic yards) of } \\
\text { low-level waste generated at each host site. }\end{array}$ \\
\hline Abnormal Event & $\begin{array}{l}\text { Potential for high dose to workers, co- } \\
\text { located workers and low dose potential } \\
\text { for the public from experimentation } \\
\text { and training. Negligible dose to } \\
\text { workers and public from a } \\
\text { transportation accident. No additional } \\
\text { cancer fatalities expected. }\end{array}$ & $\begin{array}{l}\text { Potential for high dose to workers and co-located } \\
\text { workers. Low dose potential for public from } \\
\text { ongoing work. Negligible dose to workers and } \\
\text { public from a transportation accident. No } \\
\text { additional cancer fatalities expected. }\end{array}$ \\
\hline Cumulative Effects & \begin{tabular}{l} 
No effects \\
\hline
\end{tabular} & \multicolumn{2}{|l}{} \\
\hline
\end{tabular}

Page 22

Final Environmental Assessment 


\section{Consolidation of Certain Materials and Machines for Nuclear Criticality Experiments and Training}

\subsection{Proposed Action}

\subsubsection{Human Health Effects}

Materials that could pose a nonradiological chemical hazard to workers or to the public would not be used in the proposed receipt, storage or use of the special nuclear materials required for criticality experiments and training at TA-18. Except for the radioactive materials, no other hazardous materials or hazardous operations above those routinely encountered in laboratory-type operations are anticipated under the proposed action.

The principle radioactive metals used to conduct criticality experiments with the identified materials and machines received from Hanford, SNL/NM, ORNL and INEL would be uranium and plutonium. Uranium and plutonium primarily emit low energy alpha particle radiation when they are not used in an experiment. The uranium alpha particle cannot penetrate the containment vessels or cladding materials used to contain the uranium metal under routine conditions. Since the special nuclear materials are encapsulated, in some cases with double or triple layers, no internal exposures are expected to occur. For determining hazards to workers and the public, alpha radiation is considered to be an internal hazard. Alpha monitors and routine contamination surveys of work surfaces would be used to warn of potential radiation hazards to workers. A small amount of gamma-rays would also be emitted from the uranium as a result of the natural decay of the metal when it is in storage. Plutonium emits low levels of gamma-rays and neutrons while in storage. Neutron and gamma radiation would pose an external penetrating hazard to exposed workers primarily during the set-up and take-down of experiments.

As stated, numerous safety measures are employed to ensure that there are no inadvertent criticalities when materials are in storage or in use. Stringent measures are taken to control factors that influence criticality such as the quantity of material (mass), reflection, moderation, concentration, geometry, and level of enrichment of the special nuclear materials which are necessary for an assembly to reach a critical state.

Human health effects could result from radiation exposures to the workers when they are working within the kivas, which are the proposed storage and use areas for the special nuclear material. The exposures would occur primarily from conducting inventories of materials and from set-up and take- down of criticality experiments. Workers would not be present in the kivas when the actual experiments are being conducted. It is estimated that about six involved workers, including operators, radiation control technicians and protective force (security) personnel would be required per work shift to perform a criticality experiment, including set-up and take-down. The estimated average frequency for criticality experiments under the proposed action would not change. It is assumed that six workers work in intimate contact $(\leq 30 \mathrm{~cm} / 11.8$ in) with the special nuclear

Page 23

Final Environmental Assessment 


\section{Consolidation of Certain Materials and Machines for Nuclear Criticality Experiments and Training}

materials for approximately 30 minutes per day ( 2.5 hours per week). The external radiation field associated with this material is about $5 \mathrm{mrem} / \mathrm{hr}$ at contact, $3 \mathrm{mrem} / \mathrm{hr}$ at $0.305 \mathrm{~m}(1 \mathrm{ft})$, and about $1 \mathrm{mrem} / \mathrm{hr}$ at $1 \mathrm{~m}(3.05 \mathrm{ft})$. The annual dose to an involved worker is estimated to be approximately $390 \mathrm{mrem}$. The actual annual average recorded dose to TA-18 workers over the past two years was approximately 10 mrem with the highest individual dose being 418 mrem.

An estimated dose of 390 mrem could result in an increased cancer risk to an individual worker of 0.00016 or one chance in 6,410 . For comparisons sake, the average person in the United States has a 0.20 risk, or one in 5 chance of dying from cancer based on actual mortality rates. The risk from the proposed action indicates a very low probability of occurrence of cancer in an exposed worker.

For the purpose of estimating lifetime doses to workers, the life of the proposed critical experimentation project is assumed to be approximately 30 years. Thus, collective worker dose for the life of the project (i.e. 0.390 rem x 6 persons $\times 30$ years) is estimated to be 70.2 personrem. This equates to 0.03 (i.e. less than one) total excess cancer fatalities in the exposed worker population over 30 years. Based on these calculations, no excess cancer fatalities are expected and involved workers engaged in the use of acquired materials are not expected to incur adverse health effects from exposures they receive during routine operations.

Not all workers at TA-18 are involved with criticality experimentation. Non-involved co-located workers would not handle the critical assemblies or be involved in the set-up of the experiments. Also, these workers would be restricted to remote locations, such as the control room, when experiments are conducted. The distance of these remote locations from the kivas and the shielding afforded by structures such as the control room reduces exposures to non-involved colocated workers to negligible levels. Thus, non-involved workers would not be expected to receive any additional dose as a result of this proposed action.

In addition to involved and non-involved workers, there are also trainees from various DOE sites and other federal agencies that participate in criticality training. The trainees are present for three to five days at the LACEF and participate in the set-up of the experiments. Trainees are kept at a remote location when experiments are conducted. Under no circumstances are trainees allowed to bring the assemblies to a critical state. A new class, with different trainees, is offered about every eight weeks. Because of the short duration of their exposure during the set-up and take-down of the experiments and the short duration of the class, historical doses to trainees have not been measurable. Since activities under the proposed action would be similar to ongoing training, the proposed action is not expected to have any adverse effect on trainees.

Page 24

Final Environmental Assessment 


\section{Consolidation of Certain Materials and Machines for Nuclear Criticality Experiments and Training}

The nearest private residences to the LACEF are located in White Rock. No radiation exposures to residents in White Rock are anticipated from the use of acquired nuclear materials and machines. There is a potential for exposure to members of the public using Pajarito Road from activities associated with the proposed action. Radioactive gamma-ray and neutron emissions would occur as a result of criticality experiments. Limited historical monitoring data indicate that members of the public traveling along Pajarito Road could receive a very low dose $(<1 \mathrm{mrem})$ from some types of criticality experiments. In order to eliminate or keep doses to the public as low as possible, operators at TA-18 can close Pajarito Road before conducting an experiment. Operators are required to close the road when there is a potential for a dose above background levels at the road or an actual total dose to an individual of $1 \mathrm{mrem}$ above background levels. For the majority of experiments, the dose rate at the road is much less than 5 $\mathrm{mrem} / \mathrm{hr}$. On average, road closures occur approximately 12 times a year. The requirements for closing Pajarito Road and the frequency of road closures are expected to remain unchanged under the proposed action. Therefore, the proposed action is not expected to have any adverse health effects on members of the public.

\subsubsection{Transportation and Storage of Special Nuclear Materials}

Under the proposed action, special nuclear materials would be shipped from Hanford, SNL/NM, ORNL and INEL to the LACEF at TA-18. It is estimated that only one shipment would be required from each of the originating sites to transport all the special nuclear material. This would result in a total of approximately four shipments to LANL. The materials would be moved in accordance with DOE and DOT regulations and LANL SOPs and would pose only a negligible environmental hazard or health and safety risk to workers or to the public. Transport of these materials would occur along established interstate highways. No additional intrasite transportation would be required once the materials reached TA-18. The special nuclear materials would be brought to LANL by way of either a commercial carrier or a DOE SST. All materials would be shipped in DOT specification $6 \mathrm{M}$ containers or packages and delivered to and stored at LACEF at TA-18.

Based on the analysis contained in the Appendix for routine transportation and for accident scenarios, the routine transport of these materials could result in a radiation dose to the general public located within $0.6 \mathrm{~km}(0.5 \mathrm{mi})$ on either side of the highway right-of-way of approximately 0.003 person-rem from the uranium shipments and 0.0002 person-rem from the plutonium shipments. The population traveling on the same highways as the shipments, or present at the truck stops, as well as the truck crews, would have up to approximately ten times greater dose, or up to 0.05 person-rem and 0.002 person-rem for the uranium and plutonium shipments, respectively. This radiation exposure to the affected populations is not expected to result in any additional cancer fatalities (maximum increase of 0.000025 latent cancer fatalities) to the exposed

Page 25

Final Environmental Assessment 


\section{Consolidation of Certain Materials and Machines for Nuclear Criticality Experiments and Training}

populations. In addition, the maximum dose to an individual member of the public from either -uranium or plutonium shipments is less than $0.0000005 \mathrm{rem}$. This dose would pose an estimated cancer risk to the exposed individual of 1 in 4,000,000,000, which is an exceedingly small risk. Therefore, the routine shipment of these special nuclear materials under the proposed action would not have an adverse health effect on any exposed population or any individual in the exposed population.

\subsubsection{Waste Management}

Under the proposed action, no low-level radioactive waste would be generated from the receipt and storage of special nuclear materials at TA-18. However, small amounts of low-level radioactive solid wastes from conducting criticality experiments and training courses would be generated. These wastes would consist primarily of used equipment and debris such as anticontamination clothing, gloves, boots, swipes and cleaning equipment used to maintain the kivas. Experiments and training activities associated with the proposed action would generate minimal amounts of waste and would be conducted in place of ongoing work. Because of the variability in the amount of low-level waste generated each year from current operations, the proposed action is not expected to result in an increase in the amount of waste generated each year at TA-18. Lowlevel wastes would be disposed of at the LANL low-level radioactive solid waste disposal area at TA-54. Because of the long radiological half-life of the special nuclear materials and the relatively limited use they would undergo during experimentation and training activities, the materials would not be considered to be spent nuclear materials. Therefore, no spent nuclear fuel wastes would be generated. Since the planned criticality experiments and training are not expected to add to the current waste volume for TA-18, the proposed action is not expected to have any adverse environmental effect or any effect on the disposal of low-level solid radioactive waste at LANL.

Non-contaminated solid wastes (e.g. office trash) will be taken to the Los Alamos County Landfill for disposal. The TA-18 staff would not increase and would therefore not add any additional sewage to the TA-18 sanitary sewer system. No RCRA-hazardous or mixed wastes (i.e. radioactive and hazardous) are expected to be generated.

\subsection{No Action Alternative}

The potential for environmental effects under the no action alternative would result from transportation and waste disposal actions. Under this alternative, the annual radiation doses to workers at LANL and to the public would remain unchanged. Criticality experiments would continue to be conducted using the materials currently in the inventory at TA-18. However, the training and experiments would not have access to the materials or machines available at Hanford,

Page 26

Final Environmental Assessment 


\section{Consolidation of Certain Materials and Machines for Nuclear Criticality Experiments and Training}

SNL/NM, ORNL or INEL. Doses to the public from the transportation of these materials would still occur as these materials are not expected to remain at their host sites. In addition, the generation and volumes of all waste types at TA-18 would not be expected to change. No new construction or new operations and no new emissions to the environment at TA-18 would occur under the no action alternative. The nesting shell currently at LACEF would not be used for criticality experiments but would continue to be used for NEST training.

\subsubsection{Human Health}

Human health risks under the no action alternative are expected to be unchanged for involved, non-involved workers and the public. Doses to workers and to the public would be essentially the same as those projected under the proposed action. Although the particular materials from Hanford, SNL/NM, ORNL and INEL would not be received, stored or used, other materials of a similar nature would be used in their place. The number of criticality experiments conducted at TA-18 would be essentially unchanged. The conditions for conducting operations and for limiting exposures to workers and to the public would also be unchanged under this alternative.

Therefore, criticality training and experiments that would be conducted under this alternative would be expected to have no change in effect on human health from the current operations.

\subsubsection{Transportation and Storage of Special Nuclear Materials}

The potential for radiation exposure to truck crews and to the general public from transporting special nuclear materials from Hanford, SNL/NM, ORNL and INEL to LANL would be eliminated under the no action alternative. However, the risk of a highway accident involving these materials would not be eliminated. The special nuclear materials at Hanford, SNL/NM, ORNL and INEL are not expected to remain at their current locations, indefinitely. If the DOE decides at some future date to transport these materials to another site, then the exposure to the truck crews and to the public would simply be delayed. Also, if these materials are declared to be low-level radioactive waste, the transportation of these materials to a disposal site would pose some low level of risk to the truck crews and to the general public. Since the transportation of these materials to LANL would not occur, and the future disposition of these materials is unclear if they are not sent to LANL, no adverse effects are anticipated under this alternative.

\subsubsection{Waste Management}

If the special nuclear materials or the criticality experiment machines were declared waste at their present host sites, the sites would have to add these materials to their current low-level radioactive waste streams. The volume of waste would total approximately 5 cubic meters ( 7 cubic yards) of low-level waste at each location that would require disposal. Since each of these sites currently 


\section{Consolidation of Certain Materials and Machines for Nuclear Criticality Experiments and Training}

handles low-level radioactive waste, the addition of this amount would not adversely affect the waste management programs at each of these sites. Analysis of some reprocessing of the highly enriched uranium from the CX and the HPRR assemblies or other alternatives could be required before disposal of the materials could occur. The no action alternative is not expected to have any adverse effect on the low-level radioactive waste management programs at Hanford, SNL/NM, ORNL or INEL.

\subsection{Cumulative Effects}

Cumulative effects take into account potential consequences on the human environment, either beneficial or adverse, which may result from the incremental effect of the proposed action considered together with other past, present and reasonably foreseeable future actions. Activities associated with the proposed criticality training and experiments program are not expected to have an incremental effect on the ongoing operations at TA-18. No new effluents, emissions, or waste streams are anticipated. Radiation doses to workers, the public and to the environment are not expected to change if the proposed activities are consolidated at LACEF. Although some negligible amount of radiation exposure to the general public and to the truck crews would occur from the transportation of these special nuclear materials, no adverse health effects are expected. Criticality training and experimentation would continue to occur at TA-18 at approximately the same current annual rate of three per week. No reasonably foreseeable future uses of TA-18 are planned that would affect or be affected by the proposed action. No cumulative effects are anticipated since the proposed action is not expected to increase or decrease the environmental and health effects currently experienced from operations conducted at LACEF.

Page 28

Final Environmental Assessment 


\section{Consolidation of Certain Materials and Machines for Nuclear Criticality Experiments and Training}

\subsection{ABNORMAL EVENTS}

Abnormal events or accidents are hypothetical incidents that are not a planned part of routine operations. This section considers a bounding case accident that could be associated with criticality training and experimentation at LACEF that could affect site workers, co-located workers, the public and the environment. Because of the strong similarity of the proposed action to those operations currently conducted at LACEF, the accident scenario for routine operations is taken from the DOE SAR for LACEF (DOE, 1994). Also, the potential accident scenario for the transportation of the special nuclear materials between Hanford, SNL/NM, ORNL, INEL and LANL was developed using the RADTRAN computer model (see the Appendix).

The LACEF SAR evaluated eight accident scenarios that could lead to maximum radiological consequences. The occurrence of these accidents is not based on any single physical mechanism that can occur but considers several such mechanisms together. For each of the accident scenarios, the mitigating actions of engineered safeguards and administrative controls are assumed to be minimal. For the purpose of this EA, the most severe accident that could reasonably occur that would involve the special nuclear materials discussed under the proposed action, most closely resembles an accident that involves the Godiva-IV critical assembly. The HPRR assembly, which is a part of the proposed action, is similar to the Godiva-IV critical assembly in terms of its ability to be used for fast-burst' criticality experiments.

In the LACEF SAR, the most severe accident scenario with the Godiva-IV critical assembly involves a criticality event that occurs outside of a kiva and results in an exposure time to a hypothetical individual of 30 minutes. Occasionally, operating assemblies outside of kivas is done for direct radiation dose measurements to remove the complicating effects of reflected and backscattered radiation. For an accident to occur, either an operator error or a control system malfunction or both would have to occur. The potential for operator errors or equipment malfunctions is controlled through the use of trained personnel, SOPs and strict two-person rules to check adherence to procedures and to verify proper positioning of instruments. The results of the SAR analysis indicate that some additional dose to workers and to the public would occur. However, no additional cancers would be expected for exposed workers or for the exposed population as a result of this type of accident.

Because of the need to transport special nuclear materials from Hanford, SNM/NM, ORNL and INEL to LANL under the proposed action, there is the potential for an accident to occur on a public highway. An analysis of a potential accident along a public roadway between LANL and each of the three host sites is provided in the Appendix. In addition, the distances between each of the sites, the population densities, release fractions for the uranium and accident rates for rural, suburban and urban population zones are addressed in more detail in the Appendix.

Page 29

Final Environmental Assessment 


\section{Consolidation of Certain Materials and Machines for Nuclear Criticality Experiments and Training}

RADTRAN results, as reported in this EA, give accident risks in terms of the radiation dose that would be received in the event of an accident multiplied by the probability of that accident. Thus, the results are reported in units of dose risk, instead of dose. This type of accident analysis differs from the accident analysis done in the LACEF SAR in that the SAR assumes an accident has already occurred and is concerned only with its consequences, without regard to its probability. Hence, the SAR results are reported in units of dose.

The results of the RADTRAN analysis show that the population dose risks under the proposed action are less than approximately $2.0 \times 10^{-16}$ for an accident involving uranium. The population dose risk for an accident involving plutonium is approximately $4.0 \times 10^{-12}$. These numbers indicate that the accident scenarios pose an extremely low dose risk, consequently, no additional cancers would be expected to occur in the exposed population from a potential transportation accident under the proposed action. The estimated increase in latent cancer fatalities to the exposed public would be $1.0 \times 10^{-19}$ for a uranium accident and $2.0 \times 10^{-15}$ for a plutonium accident.

These population dose risks are much less than the accident free exposures provided in Section 4.1.2 because of the historically low accident probabilities and the very low dispersibility of the materials being shipped. Consequently, the probability of an accident occuring and adversely affecting an exposed population is considered to be extremely unlikely.

Page 30

Final Environmental Assessment 


\section{Consolidation of Certain Materials and Machines for Nuclear Criticality Experiments and Training}

\subsection{AGENCIES AND PERSONS CONSULTED}

Since no new construction or site or building modifications are planned, no cultural or biological resource effects are expected. Based upon LANL environmental surveys, no threatened or endangered species or their critical habitats are known to exist in the immediate vicinity of the LACEF; consequently, no effects would occur. There are no properties present that are included in or eligible for inclusion in the National Register of Historic Places. Therefore, no coordination or consultation with either the U.S. Fish and Wildlife Service or the New Mexico State Historic Preservation Officer has occurred or is required. 


\section{Consolidation of Certain Materials and Machines for Nuclear Criticality Experiments and Training}

\subsection{PERMIT REQUIREMENTS}

The emission of radionuclides at DOE facilities is regulated by the National Emission Standards for Hazardous Air Pollutants (NESHAPs) under the Clean Air Act. The DOE Los Alamos Area Office has determined that the criticality training and experiments addressed under the proposed action would not require an air emissions permit, permit modification or additional periodic confirmatory monitoring. No other environmental permits have been determined to be needed for this project. 


\section{Consolidation of Certain Materials and Machines for Nuclear \\ Criticality Experiments and Training}

\subsection{GLOSSARY OF TERMS AND ACRONYMS}

\begin{tabular}{|c|c|}
\hline ALARA & As Low As Reasonably Achievable. Applies to radiation exposures. \\
\hline $\mathrm{Ci}$ & $\begin{array}{l}\text { Curie--a unit of radioactivity, the amount of any nuclide that undergoes } \\
\text { exactly } 3.7 \times 10^{10} \text { radioactive disintegrations per second. }\end{array}$ \\
\hline $\mathrm{cm}$ & centimeter \\
\hline criticality & $\begin{array}{l}\text { occurs when the atomic nuclei of certain kinds of radioactive materials are } \\
\text { fissioned (physically split) into different kinds of radioactive materials as a } \\
\text { result of collisions with neutrons. The splitting of the nuclei releases heat } \\
\text { energy and radiation including more neutrons which can in turn split other } \\
\text { fissionable nuclei. The reaction is considered to be critical when it reaches } \\
\text { the point where it is self sustaining. }\end{array}$ \\
\hline DOE & United States Department of Energy \\
\hline DOT & United States Department of Transportation \\
\hline EA & Environmental Assessment \\
\hline $\mathrm{EDE}$ & Effective Dose Equivalent \\
\hline EPA & United States Environmental Protection Agency \\
\hline $\mathrm{ft}$ & feet \\
\hline gr & $\begin{array}{l}\text { gram-unit of mass and weight in the metric system, equal to the mass of one } \\
\text { cubic centimeter of water. }\end{array}$ \\
\hline Hanford & DOE Hanford Plant \\
\hline HEU & Highly Enriched Uranium \\
\hline HPRR & Health Physics Research Reactor \\
\hline in & inch \\
\hline INEL & Idaho National Engineering Laboratory \\
\hline $\mathrm{kg}$ & kilogram \\
\hline $\mathrm{km}$ & kilometer \\
\hline LAAO & Los Alamos Area Office of the DOE \\
\hline LACEF & Los Alamos Criticality Experiments Facility at TA-18 \\
\hline LANL & Los Alamos National Laboratory \\
\hline $\mathrm{lb}$ & pound \\
\hline LCF & Latent Cancer Fatalities \\
\hline
\end{tabular}




\section{Consolidation of Certain Materials and Machines for Nuclear Criticality Experiments and Training}

LEU

m

mi

mrem

NEPA

NESHAPs

$\mathrm{NRC}$

ORNL

PEIS

rem

SAR

SNL/NM

SOP

SST

TA

TLD

uranium

ZPRR
Low Enriched Uranium

meter

mile

millirem--one-thousandth of a rem

National Environmental Policy Act

National Emission Standards for Hazardous Air Pollutants

United States Nuclear Regulatory Commission

DOE Oak Ridge National Laboratory

Programmatic Environmental Impact Statement

The amount of ionizing radiation required to produce the same biological effect as one roentgen of high-penetration X-rays; unit of dose equivalent for a single individual, used in the field of radiation dosimetry

Safety Analysis Report

Sandia National Laboratory, Albuquerque, NM

Standard Operating Procedure

Safe Secure Trailer

Technical Area. Term for areas at LANL

Thermoluminescent Dosimeter

A naturally occurring radioactive metal

Zero Power Research Reactor located at INEL

EXPONENTIAL NOTATION: Many values in the text and tables of this Environmental Assessment are expressed in exponential notation. An exponent is the power to which the expression, or number, is raised. This form of notation is used to conserve space and to focus attention on comparisons of the order of magnitude of the numbers (see examples):

$\begin{array}{lcc}1 \times 10^{4}= & 10000 \\ 1 \times 10^{2}= & 100 \\ 1 \times 10^{0}= & 1 \\ 1 \times 10^{-2}= & 0.01 \\ 1 \times 10^{-4}= & & 0.0001\end{array}$

Page 34

Final Environmental Assessment 


\section{Consolidation of Certain Materials and Machines for Nuclear Criticality Experiments and Training}

\subsection{REFERENCES}

DOE/EIS-0018, U.S. Department of Energy, "Final Environmental Impact Statement, Los Alamos Scientific Laboratory Site, " Springfield, VA, December, 1979.

DOE Standard. Hazard Categorization and Accident Analysis Techniques for Compliance with DOE Order 5480.23, Nuclear Safety Analysis Reports, DOE-STD-1027-92, December 1992.

DOE 1994, "Safety Analysis Report for the Los Alamos Critical Experiments Facility (LACEF) and Hillside Vault (PL-26)," Report LA-CP-92-235 as modified (UCNI text removed).

Federal Register, May 12, 1995, Washington D.C.: Government Printing Office, 1995, Vol. 60, No. 92 , p. $25697-25703$.

Federal Register, June 4, 1993, Washington D.C.: Government Printing Office, 1993, Vol. 58, No. 106, p. $31699-31700$.

Federal Register, March 30, 1993. Washington, D.C.: Government Printing Office, 1993, Vol. 58, No. 59, p. 16654 - 16655.

ICRP (International Commission on Radiological Protection), 1991. 1990 Recommendations of the International Commission on Radiological Protection, Publication 60, Pergamon Press, New York.

LANL 1995, Los Alamos National Laboratory, "Environmental Surveillance at Los Alamos During 1993, " Report LA-12973-ENV.

Remick, F.J. to Hazel O’Leary, Correspondence, July 21, 1993.

U.S. Bureau of the Census, 1994. County and City Data Book: 1994, Washington, D.C.

Page 35

Final Environmental Assessment 


\section{Consolidation of Certain Materials and Machines for Nuclear Criticality Experiments and Training}

\section{Appendix}

The transportation risk analyses were done using the RADTRAN 4 Computational System, which is maintained on the TRANSNET computer system at the Sandia National Laboratories in Albuquerque, NM. TRANSNET is publicly available and is accessible on the Internet.

Whenever a cargo of radioactive material is shipped, the people who handle the shipment and those who happen to be near the transportation route will be subjected to doses of ionizing radiation. These doses are required by Federal regulations to be extremely small, either when the transportation is incident free or in the case of accident. The RADTRAN System is designed to provide reliable estimates of the doses for incident free shipments and of the dose risks for shipments where accident probabilities are known.

The RADTRAN System requires the user to provide a substantial amount of input information ranging from characteristics of the materials being transported and the transportation routes to estimates of accident probabilities and the dispersibility of those parts of a shipment that might be released in case of accident. In addition, through its Menu System, RADTRAN provides the user with "standard" values of other parameters which would not necessarily change from one shipment to the next. These include such factors essential to the calculation as highway speeds, highway traffic density, crew size, vehicle shielding, building shielding, etc. Finally, the System provides a set of computer files, developed by the Sandia Technology Transfer Center (hence TTC files), each of which is a complete RADTRAN.input file describing the transportation of a particular radioactive cargo. The Menu system allows the user to make any desired modifications to the TTC files, to modify any other available files, or to start from scratch when setting up new input files. The set of inputs and parameters used in any RADTRAN run is given in that part of the output called the "ECHO CHECK". Some of the more significant inputs to the RADTRAN runs carried out in this analysis are listed below.

\section{A. RADTRAN Inputs:}

Shipments of uranium fuel from Hanford, SNL/NM and ORNL and shipments of plutonium from INEL to the LACEF at LANL are examined in detail in this analysis. The following information is essential input for the RADTRAN 4 accident and incident free analysis used in this EA:

Page 36

Final Environmental Assessment 


\section{Consolidation of Certain Materials and Machines for Nuclear Criticality Experiments and Training}

Table A-1. Package Shipment Information

\begin{tabular}{|l|l|l|l|l||}
\hline Shipment & No. Packages & Isotopes in Pkg. & Grams in Shpmt. & Activity, Ci/pkg \\
\hline \hline ORNL & 20 & $\mathrm{U}-235$ & $2.06 \mathrm{E}+05$ & $2.23 \mathrm{E}-02$ \\
\hline & & $\mathrm{U}-238$ & $1.52 \mathrm{E}+04$ & $2.55 \mathrm{E}-04$ \\
\hline SNL/NM & 30 & $\mathrm{U}-235$ & $2.44 \mathrm{E}+03$ & $1.78 \mathrm{E}-04$ \\
\hline & & $\mathrm{U}-238$ & $1.72 \mathrm{E}+02$ & $1.92 \mathrm{E}-06$ \\
\hline HANFORD & 10 & $\mathrm{U}-235$ & $3.88 \mathrm{E}+04$ & $8.38 \mathrm{E}-03$ \\
\hline & & $\mathrm{U}-238$ & $8.61 \mathrm{E}+05$ & $2.87 \mathrm{E}-02$ \\
\hline INEL & 1 & Pu-239 & $9.40 \mathrm{E}+04$ & $5.85 \mathrm{E}+03$ \\
\hline & & Pu-240 & $6.00 \mathrm{E}+03$ & $1.36 \mathrm{E}+03$ \\
\hline
\end{tabular}

1. The parameter values in the "RADTRAN Standard Input File" provided by the RADTRAN 4 Menu System have been used, with the following exceptions:

Stop time per shipment is changed to $2.0 \mathrm{E}-03 \mathrm{hr} / \mathrm{km}$,

(Stop time is the amount of time when the shipment is not moving, e.g., stops for fuel or food)

Minimum stop time per trip is changed to $1 \mathrm{hr}$,

The breathing rate for an individual is changed to $7.6 \mathrm{E}-05 \mathrm{cubic} \mathrm{m} / \mathrm{sec}$, and

The Transportation Index (TI) used to evaluate the dose to the exposed population from routine transportation operations is $1.0 \mathrm{mrem} / \mathrm{hr}$ dose rate at $1 \mathrm{~m}$ from the containers.

2. Weighted rural, suburban and urban population densities; and route distances, are taken from runs of the HIGHWAY module for each shipment, for use in aggregate RADTRAN runs: 


\section{Consolidation of Certain Materials and Machines for Nuclear Criticality Experiments and Training}

Table A-2. RADTRAN Population Inputs

\begin{tabular}{||l|l|l|l|r||}
\hline \hline & $\begin{array}{c}\text { Rural } \\
(\mathrm{pop} / \mathrm{sq} \mathrm{km})\end{array}$ & \multicolumn{1}{|c|}{$\begin{array}{c}\text { Suburban } \\
(\mathrm{pop} / \mathrm{sq} \mathrm{km})\end{array}$} & $\begin{array}{c}\text { Urban } \\
(\mathrm{pop} / \mathrm{sq} \mathrm{km})\end{array}$ & $\begin{array}{c}\text { Distance } \\
(\mathrm{km})\end{array}$ \\
\hline \hline ORNL & 7.9 & 320.1 & 2091.5 & 2256.2 \\
\hline SNL/NM & 8.7 & 479.9 & 2067.0 & 160.9 \\
\hline HANFORD & 4.4 & 412.4 & 2062.5 & 1990.7 \\
\hline INEL & 4.4 & 420.2 & 2087.7 & 1363.1 \\
\hline
\end{tabular}

3. There are no "RADTRAN standards" for the parameters used in accident analyses. In building an input file for accident analysis, the user must first define "accident severity categories" (from "least" to "most" severe) in terms of the fraction of a shipment that would be released to the environment by an accident in each category. In order to be conservative in estimating effects, fractions of shipments released in the event of an accident were assigned to the more severe categories (i.e., 4 through 8). The actual release fractions used (i.e., 0.001) for each shipment by severity category were determined using DOE standards (DOE, 1994).

After assigning fractions released by severity category, one must decide on what fraction of accidents would be found in each severity category. This must be done for rural, suburban and urban population zones. Finally, accident rates, in accidents per vehicle kilometer, must be provided. The various values assigned in this analysis are shown in Tables A-3 and A-4.

Table A-3. Fractions of the Shipment Released in Each of Eight Severity Categories

\begin{tabular}{|l|l|l|l|l|l|l|l|}
\hline 1 & 2 & 3 & 4 & 5 & 6 & 7 & 8 \\
\hline 0.0 & 0.0 & 0.0 & 0.001 & 0.001 & 0.001 & 0.001 & 0.001 \\
\hline
\end{tabular}

Accident rates (per vehicle-km) for Rural (2.08E-08), Suburban (4.16E-07), and Urban (2.34E-06) population zones were assigned. Accident rates are measures of the probability of an accident. In a correctly done risk assessment it is necessary to combine the probability of an accident with the radiation dose that would be received in the event of an accident. Therefore, RADTRAN outputs for accident analyses are probabilistic and must be reported in units of dose risk, while outputs for incident-free transportation are deterministic and are reported in units of dose alone.

Page 38

Final Environmental Assessment 


\section{Consolidation of Certain Materials and Machines for Nuclear Criticality Experiments and Training}

Table A-4. Fraction of Accidents by Severity Category

\begin{tabular}{|c|c|c|c|c|c|c|c|}
\hline \multicolumn{8}{|l|}{ Rural: } \\
\hline $6.63 \mathrm{E}-01$ & $\begin{array}{c}3.94 \mathrm{E}- \\
01\end{array}$ & $\begin{array}{c}3.00 \mathrm{E}- \\
03\end{array}$ & $\begin{array}{c}3.00 \mathrm{E}- \\
06\end{array}$ & $\begin{array}{c}5.00 \mathrm{E}- \\
06\end{array}$ & $\begin{array}{c}7.00 \mathrm{E}- \\
06\end{array}$ & $\begin{array}{c}8.00 \mathrm{E}- \\
06\end{array}$ & 7.5E-06 \\
\hline \multicolumn{8}{|l|}{ Suburban: } \\
\hline $6.62 \mathrm{E}-01$ & $\begin{array}{c}3.94 \mathrm{E}- \\
01\end{array}$ & $\begin{array}{c}4.00 \mathrm{E}- \\
03\end{array}$ & $\begin{array}{c}4.00 \mathrm{E}- \\
06\end{array}$ & $\begin{array}{c}3.00 \mathrm{E}- \\
06\end{array}$ & $\begin{array}{c}2.00 \mathrm{E}- \\
06\end{array}$ & $\begin{array}{c}1.00 \mathrm{E}- \\
06\end{array}$ & $\begin{array}{c}1.50 \mathrm{E}- \\
06\end{array}$ \\
\hline \multicolumn{8}{|l|}{ Urban: } \\
\hline $6.04 \mathrm{E}-01$ & $\begin{array}{c}3.95 \mathrm{E}- \\
01\end{array}$ & $\begin{array}{c}3.80 \mathrm{E}- \\
04\end{array}$ & $\begin{array}{c}3.80 \mathrm{E}- \\
07\end{array}$ & $\begin{array}{c}2.50 \mathrm{E}- \\
07\end{array}$ & $\begin{array}{c}1.30 \mathrm{E}- \\
07\end{array}$ & $\begin{array}{c}1.00 \mathrm{E}- \\
07\end{array}$ & $9.00 \mathrm{E}-08$ \\
\hline
\end{tabular}

\section{B. RADTRAN Outputs:}

The total radiation dose to which the general public would be exposed in incident free. transportation of uranium from ORNL, SNL/NM and Hanford is no greater than 0.003 personrem. The exposed population includes all individuals located within $0.6 \mathrm{~km}(0.5 \mathrm{mi})$ on either side of the right-of-way. The population traveling on the same highways as the shipment, or present at the truck stops, as well as the truck crews themselves, would have up to approximately ten times greater dose, or up to 0.05 person-rem. The maximum dose to a single individual member of the public is less than 0.0000005 rem. Population dose risks in case of accident are less than approximately $2.00 \mathrm{E}-16 \mathrm{rem}$. They are significantly less than the incident-free exposures because of the historically low accident probabilities (from 2.08E-8 to 2.34E-6 accidents per vehicle-km, from rural to urban highways) and the very low dispersibility of the materials being shipped. All of the calculated doses are below background radiation levels because the shipments are made in compliance with Federal regulations. For the sake of comparison, the average background radiation dose to an individual in the U.S. is approximately 360 mrem per year. In units of dose to the total population along the selected transportation routes, the background radiation dose is on the order of $3.60 \mathrm{E}+04$ person-rem per year.

The total radiation dose to which the general public would be exposed in incident free transportation of plutonium from INEL is no greater than 0.0002 person-rem. The exposed population includes all individuals located within $0.6 \mathrm{~km}(0.5 \mathrm{mi})$ on either side of the right-ofway. The population traveling on the same highways as the shipment, or present at the truck stops, as well as the truck crews themselves, would have up to approximately ten times greater dose, or up to 0.002 person-rem. The maximum dose to a single individual member of the public 


\section{Consolidation of Certain Materials and Machines for Nuclear Criticality Experiments and Training}

is less than 0.00000002 rem. Population dose risks in case of accident are less than approximately $4.00 \mathrm{E}-12 \mathrm{rem}$. They are significantly less than the incident-free exposures because of the historically low accident probabilities (from about $2.08 \mathrm{E}-8$ to $2.34 \mathrm{E}-6$ accidents per vehicle-km, from rural to urban highways) and the low dispersibility of the materials being shipped.

Doses for incident free shipments of uranium are about the same as the doses for incident free shipments of plutonium because they both must comply with regulatory requirements. Radioactive materials are assumed to be packaged so as not to exceed a dose rate of $1.0, \mathrm{mrem} / \mathrm{hr}$ at a distance of one meter. Although the population dose risks are extremely low for both uranium and plutonium, the dose risks in case of an accident are greater for plutonium shipments because the radioactivity of plutonium is greater than that of uranium. The calculated doses from accidents and from incident free travel are well below doses received from background radiation. The average background radiation dose is approximately $360 \mathrm{mrem}$ per year. In units of dose to the total population along the selected transportation route, it is on the order of $3.60 \mathrm{E}+04$ person-rem per year. The following section gives excerpts from the output file of the RADTRAN analysis.

\section{CRITEXEA - ORNL:}

\section{A. INCIDENT-FREE POPULATION EXPOSURE (dose) IN PERSON-REM

$\begin{array}{cccccccc}\text { PASSENGER CREW } & \text { HANDLERS } & \text { OFF LINK } & \text { ON LINK } & \text { STOPS } & \text { STORAGE } & \text { TOTAL } \\ 0.00 \mathrm{E}+00 & 5.07 \mathrm{E}-02 & 0.00 \mathrm{E}+00 & 2.88 \mathrm{E}-03 & 2.69 \mathrm{E}-02 & 3.38 \mathrm{E}-02 & 0.00 \mathrm{E}+00 & 1.14 \mathrm{E}-01\end{array}$

MAXIMUM INDIVIDUAL IN-TRANSIT DOSE: 3.06E-07 REM

\section{B. ACCIDENT SCENARIO POPULATION RISK(dose risk) IN PERSON REM}

$\begin{array}{rcccccl}\text { GROUND } & \text { INHALED } & \text { RESUSPD } & \text { CLOUDSH } & \text { INGESTION } & \text { TOTAL } \\ \text { U235 } & 5.18 \mathrm{E}-17 & 1.85 \mathrm{E}-17 & 8.46 \mathrm{E}-17 & 5.41 \mathrm{E}-22 & 0.00 \mathrm{E}+00 & 1.55 \mathrm{E}-16 \\ \text { U238 } & 5.23 \mathrm{E}-21 & 2.12 \mathrm{E}-19 & 9.64 \mathrm{E}-19 & 4.18 \mathrm{E}-27 & 0.00 \mathrm{E}+00 & 1.18 \mathrm{E}-18\end{array}$

TOTALS: $5.18 \mathrm{E}-17 \quad 1.87 \mathrm{E}-17 \quad 8.56 \mathrm{E}-17 \quad 5.41 \mathrm{E}-22 \quad 0.00 \mathrm{E}+00 \quad 1.56 \mathrm{E}-16$ 
II. CRITEX EA - SNL/NM :

A. INCIDENT-FREE POPULATION EXPOSURE IN PERSON-REM

PASSENGER CREW HANDLERS OFF LINK ONLINK STOPS STORAGE TOTAL

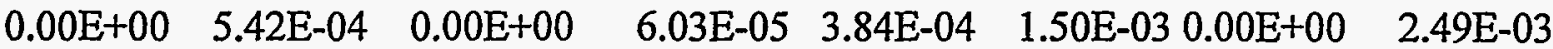

MAXIMUM INDIVIDUAL IN-TRANSIT DOSE: 4.59E-08 REM

B. ACCIDENT SCENARIO POPULATION RISK IN PERSON REM

$\begin{array}{ccllllll} & \text { GROUND } & \text { INHALED } & \text { RESUSPD } & \text { CLOUDSH } & \text { INGESTION } & \text { TOTAL } \\ \text { U235 } & 6.58 \mathrm{E}-20 & 2.35 \mathrm{E}-20 & 1.07 \mathrm{E}-19 & 6.86 \mathrm{E}-25 & 0.00 \mathrm{E}+00 & 1.97 \mathrm{E}-19 \\ \mathrm{U} 238 & 6.27 \mathrm{E}-24 & 2.54 \mathrm{E}-22 & 1.15 \mathrm{E}-21 & 5.01 \mathrm{E}-30 & 0.00 \mathrm{E}+00 & 1.41 \mathrm{E}-21\end{array}$

TOTALS: $6.58 \mathrm{E}-20 \quad 2.38 \mathrm{E}-20 \quad 1.09 \mathrm{E}-19 \quad 6.86 \mathrm{E}-25 \quad 0.00 \mathrm{E}+00 \quad 1.98 \mathrm{E}-19$

III. CRITEX EA - Hanford:

A. INCIDENT-FREE POPULATION EXXPOSURE IN PERSON-REM

PASSENGER CREW HANDLERS OFF LINK ONLINK STOPS STORAGE TOTAL

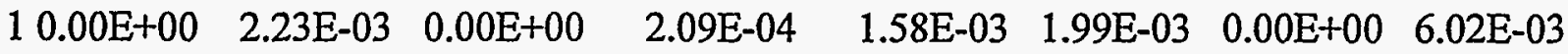

MAXIMUM INDIVIDUAL IN-TRANSIT DOSE: 1.53E-08 REM

B. ACCIDENT SCENARIO POPULATION RISK IN PERSON REM

$\begin{array}{lrllllll} & \text { GROUND } & \text { INHALED } & \text { RESUSPD } & \text { CLOUDSH } & \text { INGESTION } & \text { TOTAL } \\ \text { U235 } & 1.09 \mathrm{E}-17 & 3.91 \mathrm{E}-18 & 1.79 \mathrm{E}-17 & 1.14 \mathrm{E}-22 & 0.00 \mathrm{E}+00 & 3.27 \mathrm{E}-17 \\ \mathrm{U} 238 & 3.31 \mathrm{E}-19 & 1.34 \mathrm{E}-17 & 6.10 \mathrm{E}-17 & 2.64 \mathrm{E}-25 & 0.00 \mathrm{E}+00 & 7.47 \mathrm{E}-17\end{array}$

TOTALS: $1.13 \mathrm{E}-17 \quad 1.73 \mathrm{E}-17 \quad 7.88 \mathrm{E}-17 \quad 1.14 \mathrm{E}-22 \quad 0.00 \mathrm{E}+00 \quad 1.07 \mathrm{E}-16$ 


\section{Consolidation of Certain Materials and Machines for Nuclear Criticality Experiments and Training}

IV. CRITEX EA-INEL:

A. INCIDENT-FREE POPULATION EXPOSURE IN PERSON-REM

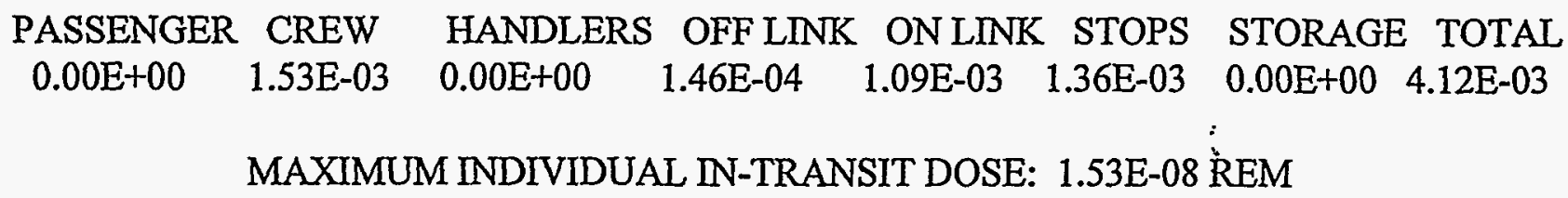

B. ACCIDENT SCENARIO POPULATION RISK IN PERSON REM

GROUND INHALED RESUSPD CLOUDSH INGESTION TOTAL

$\begin{array}{llllll}\text { PU239 2.75E-15 } & 4.93 \mathrm{E}-13 & 2.25 \mathrm{E}-12 & 2.96 \mathrm{E}-21 & 0.00 \mathrm{E}+00 & 2.75 \mathrm{E}-12\end{array}$

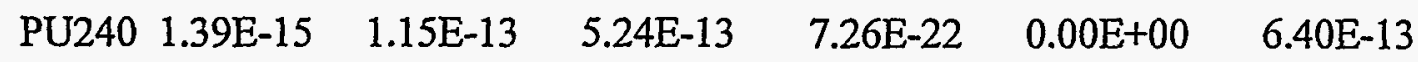

TOTALS: $4.14 \mathrm{E}-15 \quad 6.08 \mathrm{E}-13 \quad 2.77 \mathrm{E}-12 \quad 3.68 \mathrm{E}-21 \quad 0.00 \mathrm{E}+00 \quad 3.39 \mathrm{E}-12$

\section{Health Effects:}

The Radtran System has currently disabled its hẹalth effects module pending revisions that will use the latest most up-to-date data. Using the standard multipliers (ICRP, 1991) to convert from radiation dose to excess cancer fatalities of 4.0E-4 per rem for workers and 5.0E-4 per rem for the general population, leads to estimates of approximately $2.0 \mathrm{E}-5$ and $1.5 \mathrm{E}-6$, or 2.0 expected additional cancer fatalities per 100 thousand workers and 1.5 expected additional cancer fatalities per 1 million people in the general population. However, since the number of workers and the number of persons in the general population that could reasonably receive an exposure that results in a measurable dose are well below 100 thousand and 1 million, respectively, no additional cancer fatalities are expected.

\section{References:}

DOE 1994, "DOE Handbook, Airborne Release Fractions, Rates and Respirable Fractions for Nonreactor Nuclear Facilities, Volume 1 - Analysis of Experimental Data," DOE-HNBK-3010YR, Washington, DC, October, 1994. 